\title{
economics-of-security.eu
}

Tilman Brück, Patricia Justino, Philip Verwimp and Alexandra Avdeenko

\section{Identifying Conflict and Violence in Micro-Level Surveys}

July 2010

Economics of Security Working Paper 38 
Correct citation: Brück, T., Justino, P., Verwimp, P. and Avdeenko, A. (2010). "Identifying Conflict and Violence in Micro-Level Surveys". Economics of Security Working Paper 38, Berlin: Economics of Security.

First published in 2010

(c) Tilman Brück, Patricia Justino, Philip Verwimp and Alexandra Avdeenko 2010

ISSN: 1868-0488

For further information, please contact:

Economics of Security, c/o Department of International Economics, German Institute for Economic Research (DIW Berlin), Mohrenstr. 58, 10117 Berlin, Germany.

Tel: +49 (0)30 $89789-277$

Email: eusecon@diw.de

Website: www.economics-of-security.eu 
Discussion Paper

\title{
Identifying Conflict and Violence in Micro-Level Surveys
}

\author{
Tilman Brück*, Patricia Justino, \\ Philip Verwimp and Alexandra Avdeenko ${ }^{1}$
}

Berlin, 15 July 2010

key words: conflict, violence, war, individuals, households, survey, questionnaire, methodology

JEL codes: C81, D74, F52, O12

* corresponding author: DIW Berlin, Mohrenstraße 58, 10117 Berlin, Germany, Email: tbrueck@diw.de, Tel: +49-30-89789-591/-441, Fax: +49-30-89789-108

\footnotetext{
${ }^{1}$ We are grateful to Eszter Magyar, Sebastian Neuenfeldt and Kim Zietlow for excellent research assistance. The usual disclaimer applies.
} 


\section{Executive Summary}

The overall goal of the report is to increase the capacity of researchers and policy makers to identify comparatively, and across time, how individuals, households and communities are affected by violent conflict. The report provides an extensive overview of existing practices and datasets used in this field of research. We investigate existing methodologies and data-bases used to operationalize the variables of interest and discuss the channels linking violent conflict to individual and household welfare. Special attention is paid to methodological issues on how to design a module and operationalize variables that allow researchers to analyze the welfare effects of violent conflict across countries and across time.

We develop and discuss a generic household module that can be easily inserted into future socio-economic surveys implemented in conflict-affected countries. This module will enable researchers to address specific violencerelated issues comparatively across different conflict settings and systematically across time. The module proposed builds on previous

experiences on survey designs in conflict-affected areas. We review existing conflict- and violence-related questionnaires, with a special focus on World Bank's Living Standard Measurement Surveys (LSMS), and propose suggestions on how to improve questionnaires in order to deepen the understanding of the nature of violent conflict and the channels whereby conflict and violence affect the welfare characteristics and choices of individuals and households in conflict areas. 


\section{Table of Contents}

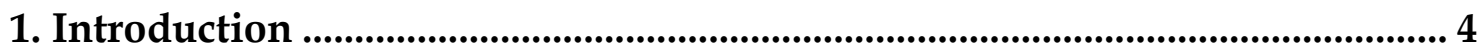

2. Practices in and Opportunities for Assessing a Generic Conflict Module... 6

2.1 Purposively Designed Surveys .................................................................... 7

2.2 Use of Existing Socio-Economic Surveys..................................................... 12

3. Methodology: Designing and Contextualizing a Generic Violent Conflict

Module .......................................................................................................................... 17

3.1. Defining and Measuring Key Terms: General and Context-Specific ....... 18

3.1.1. The Concept of Violent Conflict............................................................ 18

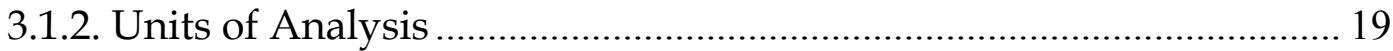

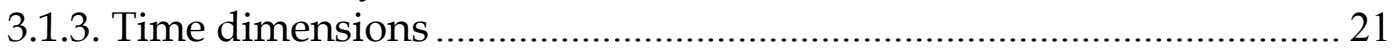

3.2. Comprehensiveness and Ethics ............................................................... 22

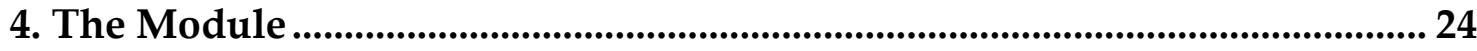

4.1. Section A: Changes in Demographic Characteristics.................................. 24

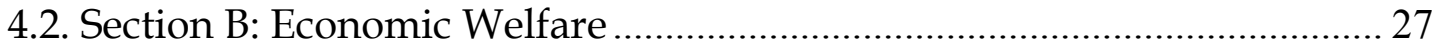

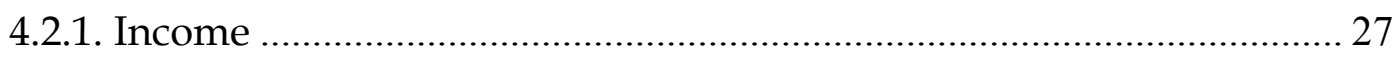

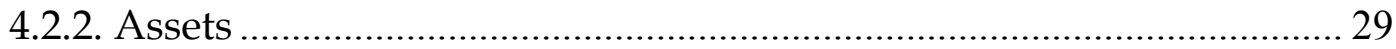

4.3. Section C: Activities during Conflict............................................................ 30

4.4. Section D: Physical Harm and Health......................................................... 34

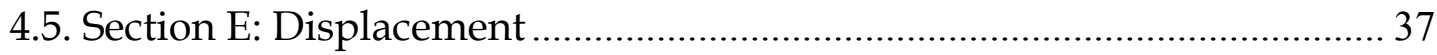

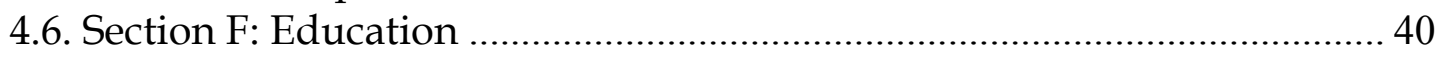

4.7. Section G: Perceptions of Security ........................................................... 42

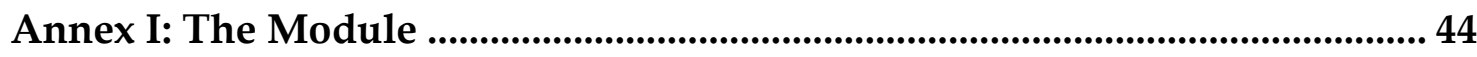

Section A: Changes in Demographic Characteristics....................................... 45

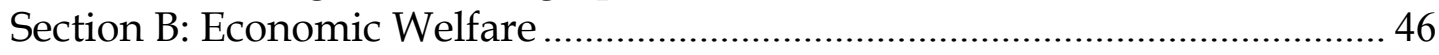

Section C: Activities during Conflict................................................................ 47

Section D: Harm and Health ....................................................................... 48

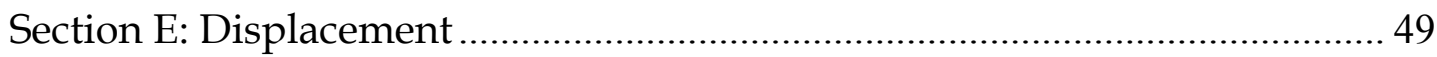

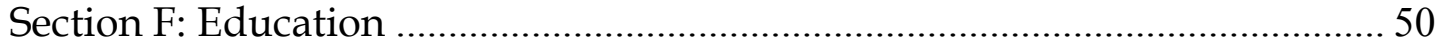

Section G: Perceptions of Security …………………...................................... 50

Annex II: Surveys with Conflict-Related Questions by Regions ....................... 51

Project Team............................................................................................................... 54

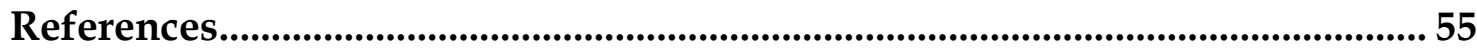




\section{Introduction}

While there has been a growing consensus that development and poverty reduction efforts cannot be disassociated from the constraints caused by violent conflict (ERD 2009; WDR 2011), we have limited rigorous evidence of how violent conflict is both experienced and perceived by individuals, households and communities affected by armed violence. Although the World Bank and other institutions have conducted several micro-level socio-economic surveys in conflict-affected countries, only a few of these explicitly acknowledge the (prior) existence of violent conflict in those countries when designing sampling frames and formal questionnaires (Bozzoli and Brück 2009b). Questionnaires used in standard household surveys implemented in countries affected by violence and conflict (e.g. Nigeria, Indonesia, Colombia, Rwanda, South Africa, Pakistan, and Liberia) rarely feature questions capturing the causes and consequences of violence in the lives of those affected by violent conflict. When they do, these are not systematically implemented, nor do they allow consistent comparison across different settings. Due to a lack of information at the microlevel, research on violent conflict has generally relied on more easily standardized macro-level measures of violent conflict such as the number of battle deaths per country per year. This approach, however, makes it hard to know who is affected by the violence, to what degree, what the welfare implications are and in particular what the channels are by which violence affects welfare and behaviour. It is also nearly impossible to capture social and political transformations that occur in societies affected by armed violence.

The current state of the art of empirical research on violent conflict offers therefore considerable opportunity for improving our knowledge of violent conflict itself, its functions and dynamics, as well as the impact of conflict on behaviour, welfare and overall development. In particular, advances in existing research require further efforts and methodological improvement to measure inter-temporal changes in the effects of conflict (the "conflict legacy") in a given country and to analyze systematically the nature and effects of violent conflict across regions, sectors or groups within a country, across countries and across time.

This paper is an attempt to address these empirical gaps by developing a generic conflict identification module. The module aims to identify manifestations of violent conflict at the individual and household level through direct and indirect channels.

Violent conflict may impact on welfare directly, through physical and psychological harm, death or illness of household members, destruction of assets and human capital, and displacement. Conflict may also have an indirect impact through its effects on income, prices, wages, access to markets, access to safety nets, social, economic and political institutions, community relations and overall levels of insecurity (Justino 2009). The module additionally includes 
questions about the kind of violence experienced by individuals and households, its timing, the identity of perpetrators, and the measures and actions taken to cope with and limit exposure to violence and its impacts.

The contribution of this conflict module to overall understanding of socio-economic change is to focus our questions on those aspects of the microlevel functioning of violence and conflict that are not ordinarily captured in other sections of standard socio-economic questionnaires. The questions in the module aim at contextualizing violence within communities as much as possible while preserving the quantitative and comparative nature of the data collection effort.

We do not aim to develop an instrument for the estimation of war deaths. ${ }^{2}$ Nor do we aim to estimate or portray more extensively the frequency of different types of violent events. ${ }^{3}$ Even though the module will collect information on the occurrence of certain events and deaths in the household, the main purpose of the module is to allow further understanding on the impact of violent conflict events on the lives and livelihoods of affected people and communities, and on forms of behaviour that may impact on the nature, functioning and evolution of the conflict itself.

We define violent conflict as the systematic breakdown of the social contract resulting from and/or leading to changes in social norms, which involve violence instigated through collective action. This notion includes an element of mass or group behaviour and captures a variety of conflict intensities spanning from violent protests and riots to coups, revolutions, civil wars, genocide, international wars and terrorism. It excludes forms of conflict grounded on labour relations that do not result in violence, such as strikes and lockouts and other forms of labour action; violence instigated by individuals for self-gain that do not involve mass conflict, such as crime; and intrahousehold forms of violence that do not degenerate into group conflict, including domestic violence and bargaining processes within the household. We consider 'conflict-affected areas' those that have experienced significant direct effects of violent conflict. We acknowledge the fact that many violent conflicts only occur in some parts of some countries, hence making a distinction between conflict-affected countries and conflict-affected areas necessary. 4

The additional value of the conflict module proposed is that it enables researchers to probe deeper into the manifestations, extent and magnitude of group-based violence in addition to detailed questions on socio-economic

\footnotetext{
2 See Roberts, Lafta et al. (2004); Burnham, Lafta et al. (2006); Burnham (Roberts, Lafta, Garfield et al. 2004; Burnham, Lafta, Doocy et al. 2006; 2008) and critical discussion by Spagat, Mack et al. (Spagat, Mack, Cooper et al. 2009) and by the International Rescue Committee (IRC), see also Human Security Report 2008/9.

${ }^{3}$ This is done in the IISS Armed Conflict Database, CEWARN Reporter or ACLED, and CERAC. ${ }^{4}$ An example may be the civil war in Northern Uganda, which was devastating at the local level but had rather fewer effects in other parts of Uganda.
} 
behaviour and characteristics of samples of interest. The module represents a first step in setting guidelines and standards to measure violent conflict at the micro-level across surveys, countries and time in order to enable the systematic understanding and evaluation of the impact, nature and legacy of violent conflict. The module is designed to be included - with minor modifications depending on the local context - in future micro-level surveys by the World Bank and other stakeholders in government, civil society and academia. ${ }^{5}$ Handling a ready-made module allows saving costs and provides the opportunity to effectively use staff and facilities, in addition to facilitating cross-country comparisons based on local realities and observed change at the micro-level rather than more unreliable aggregated country-level data.

While we propose a general module to capture the effects of conflict and violence comparatively across countries and times, we acknowledge that crucial differences in the nature and evolution of conflicts will exist in different places and over time. The module will therefore be sufficiently flexible to allow for shifting of definitions over time as well as space according to changes in cultural differences, the occurrence of other shocks and changes in fundamental psychological, legal, economic, social or political structures that cannot be fully understood in general terms.

\section{Practices in and Opportunities for Assessing a Generic Conflict Module}

This section reviews the different paths scholars have taken to conduct empirical research on the impact of violent conflict. This work can be distinguished by disciplines (e.g. economics, political science, anthropology) and by the levels of analysis. The section outlines the characteristics, as well as the limitations, of current practices in the measurement and analysis of the effects of violent conflict on (individual and household) welfare.

Economic research since the early 1990s has concentrated in explaining the risk of civil war grounded on factors such as resource dependence (e.g. positive effects are found in Collier and Hoeffler (1998), Hegre (2002), Elbadawi and Sambanis (2002), or Fearon and Laitin (2003)), poverty and political instability (e.g. Fearon and Laitin (2003)), weak state capacity (Fearon 2004), amongst others.

In recent years, this macro-level perspective has come under criticism for not being able to identify important endogenous dynamics of violent conflict the complex linkages, causal relationships and transmission mechanisms involved ${ }^{6}$. New emerging research on violent conflict has promoted a micro-

\footnotetext{
${ }^{5}$ An example of how modules on different topics can be included provides for example the Multiple Indicator Cluster Survey (MICS), a large series of Multiple Year Cross-Section surveys on child well-being and on mother reproductive health undertaken by UNICEF.

${ }^{6}$ See Lichbach (1989) for an early review; and Verwimp, Justino and Brück (2009), Justino (forthcoming 2010) for recent discussions.
} 
level perspective in order to better understand the role of local conflict dynamics on the outbreak and duration of civil wars, or the impact of armed conflicts on the lives, livelihoods and human capital of individuals and households affected by violence (Kalyvas and Kocher 2009; Justino forthcoming 2010; Verwimp, Justino and Brück 2009). This new body of research has proposed considerable steps to advance our knowledge of the complex causes of conflict, including important theoretical insights on the emergence of violent collective action (Goodwin 2001; Petersen 2001; Wood 2003; Blattman 2009; Beber and Blattmann 2010), on how competing groups form, interact and behave (Grossman 1991; Gates 2002), on the organization and functions of violence (Keen 1998; Cramer 2006; Kalyvas 2006) and on the internal organization of armed groups and motivations of individuals that form them (Richards 1996; Weinstein 2007; Humphreys and Weinstein 2008). The last few years have also witnessed an increased focus on the consequences of violent conflict on short- and long-term health outcomes (Bundervoet, Verwimp and Akresh 2009; Akresh, Verwimp and Bundervoet forthcoming 2011), schooling (Akresh and Walque 2008; Justino forthcoming 2010), and agricultural coping strategies (Bozzoli and Brück 2009a; Brück and Schindler 2009a).

This new body of research has also enabled to enhance theoretical understanding of different types of vulnerability (Justino 2009), and has been used to assess the efficiency of policy interventions in conflict-affected areas and countries (see for instance Ibáñez and Velásquez (2009)).

Overall, this relatively new strand of economics literature has proved to be an important tool in shedding light on the nature of conflict processes, as well as the trajectories of welfare outcomes of affected populations. However, a new approach to measuring and identifying conflict at the micro-level is needed to address these issues satisfactorily (Bozzoli and Brück 2009b).

Below we review recent methodological contributions of this field and reflect on the insights they provide for the development of our conflict module. We focus on the following methodological development: (i) the design and implementation of purposively designed surveys to uncover conflict-related information; and (ii) the use of existing socio-economic surveys that have not been designed for the purpose of conflict analysis but have been used creatively by researchers.

\subsection{Purposively Designed Surveys}

The advances and insights gained from micro-level analyses have been promoted, but have also significantly advanced, the development of new and original micro-level datasets. One approach of empirical work in the field of micro-level analyses is based on data specifically collected to uncover causes 
and functions of violent conflict at the micro-level. This has been so far an uncommon approach and includes a limited number of surveys. ${ }^{7}$

\section{Ex-Combatant Surveys}

Several surveys focus on the identifying the experiences of specific population groups, notably former soldiers and members of rebel movements. Pioneering work in this area was done by Humphreys and Weinstein (2004; 2008). Excombatant surveys seek to determine ex-combatants' geographic location of the respondents throughout the course of the war. ${ }^{8}$ For different snapshots in time the respondents are asked, whether they joined "Which faction were you a member of?" Therefore, they identify not only a date, but also an event, which makes it easier for the respondent to remember the situation. The main focus is set on the soldiers' actions during the war at different locations ('in/during combat', 'near the base', and 'within the unit itself'). These questions do not ask whether certain events, such as theft, rape and wounding someone, were undertaken by the respondent, but whether they were observed. The surveys focus also on the re-integration process of these ex-combatants. ${ }^{9}$ Overall, these surveys enable to portray the multi-causal mechanism involved in the decision on participate in armed conflicts, and to differentiate between those who were abducted, voluntarily joined, and abstained from the armed movement.

Arjona and Kalyvas (2008) also look at the individual characteristics for joining armed groups in Colombia, relying on survey data from 732 excombatants of a leftist guerrilla group and a right-wing paramilitary group. This survey offers extensive information on joining, group organization and practices, and demobilization. Guichaoua's (2007) uses a similar instrument to examine motivations to join insurgent and incumbent groups in Nigeria.

An important contribution to the design of surveys to monitoring the micro effects of violent conflict is the Survey of War Affected Youth (SWAY) in Northern Uganda directed by Chris Blattman and Jeannie Annan. ${ }^{10}$ The representative survey was conducted in 2005 and 2006 amongst 1016

\footnotetext{
${ }^{7}$ A similar direction is the proliferation of qualitative analyses of populations affected by violent conflict, based on small samples and limited geographic locations (for instance, Lubkemann (2008)), but containing a wealth of information on conflict processes, community structures and institutional changes at the local level. Due to the purpose of this paper, we focus this section only on quantitative surveys.

8 The study also compared the situation of combatant to non-combatants within the same geographic sampling clusters.

${ }^{9}$ See also Taylor (2007); and Fearon, Humphreys and Weinstein (2009), and for Sierra Leone PRIDE/JCTJ (2002). A useful website for the collection of information on different surveys has been: Post-Conflict and Ex-Combatant Surveys, http://www.columbia.edu/ mh2245/XCSURVEYS/ (28/04/2010).

${ }^{10}$ See http://chrisblattman.com/projects/sway/ for a description of the project.
} 
households and 741 male youth in eight sub-counties. The survey allows assessing different dimensions of vulnerability and resilience in different social contexts, and to gain knowledge on aspects such as education and training, livelihoods, health, substance abuse, the magnitude, incidence, and impacts of war violence and abduction, as well as on the return and reintegration of former abductees. This work has been used to provide recommendations on redesigning governmental and non-governmental assistance.

One of the remarkable features of the survey is the design of locally adapted instruments, for example to measure psychosocial well-being, differentiating among others between different 'symptoms of emotional distress' (e.g. 'nightmares and insomnia', 'crying when thinking of the past'). However, despite insights gained from field work, it is recognized that the extent of adaptation to cultural and contextual specificity is limited as it was not possible to measure aspects of peer support, social networks, and community-wide factors. A similar measurement of the exposure to violence and emotional distress has also been used in the Northern Uganda Social Action Fund Youth Opportunities Project (NUSAF YOP 2008).

The survey allows also the measurement of the scope and nature of violence experienced by different population groups. Based on semi- structured interviews, the team has developed a catalogue of 31 most common as well as most brutal and traumatic acts of violence experienced (e.g. "You were forced to kill a family member or friend" "You were forced to betray a family member or friend", see Annan, Blattman and Horton (2006: 52)).

Eric Mvukiyehe, Cyrus Samii, and Gwendolyn Taylor conducted in 2007 over 3000 interviews primarily focusing on armed group recruitment, especially the reasons for joining, in the civil war in Burundi (1993-2007). This survey was applied to both combatants and non-combatants, allowing identifying how far experiences differ between different groups. The survey covers some acts of violence: The question on the "reason for death" - "war" is directly linked is whether and when the person was a combatant; People experiencing "Physical mistreatment or sexual abuse" and/ or forced labour, and can directly identify groups of perpetrators ${ }^{11}$. Similarly, the Indonesian GAM Reintegration Needs Assessment 2005 contains a module on 'Household: Conflict Exposure' asking about the timing and the perpetrators.

Genocide and Atrocities Surveys

11 "Those abominable crimes have been committed mostly by government forces (FAB), fighting groups (militias), or by both similarly?". See also on Nepal (Samii, Gilligan and Eck 2009) 
The Genocide Transition Survey (2000) conducted in Rwanda is one of the first examples of the potential of survey research in conflict-affected settings. ${ }^{12}$ Verwimp tracked the fate of members of households who had been interviewed in a nationwide agricultural survey prior to the 1994 genocide. Apart from the insights into the profile of perpetrators (Verwimp 2005) and victims (Verwimp 2003), his work showed that tracking is possible even under the difficult circumstances of a post-conflict society. Verwimp notes that the success of the tracking exercise depended on the extensive preparation of the project, the long-term presence of the researcher in the field as well as the wellorganised nature of Rwandese society (e.g. people on the hills know of each other's whereabouts).

An opportunity to link violent acts and the victims of these acts with a description of the perpetrator is offered by the Darfur Refugee Questionnaire (DRQ). This questionnaire used by the US State Department to define the killings in Darfur as genocide, is specifically designed to capture the extent of violence and conflict afflicted on a given population (in this case a refugee population living in camps) as well as particulars about the type of violence and the profile of the perpetrators. The work by Totten and Markusen (2006) provides insights in the how this survey was conducted.

Kalyvas and Kocher (2009) make use of a unique community-level dataset on the dynamics of violence in the Vietnam War, the Hamlet Evaluation System (HES), collected by the US military. With the help of sophisticated instruments which differentiate between 'selective terrorism (kidnapping and assassination)' against local leaders of a hamlet (clusters of dwellings) and 'non-selective terrorism', such as 'mining' and 'bombing of a public place', Kalyvas and Kocher have contributed significantly to the understanding of irregular conflicts. They identify Vietcong selective violence and the indiscriminate violence by the South Vietnamese and US militaries as a function of territorial control. Their findings show that most civilian causalities happen due to the use of selective violence in not fully controlled areas.

\section{Displaced People Surveys}

Another aspect of violent conflict studied in the literature concerns welfare losses suffered by displaced people. Deininger, Ibáñez and Querubin (2004) use a household survey applied by the Catholic Church (RUT) in Colombia to investigate the decisions to return after displacement. Using this information, they identify agriculture employment, access to land and the existence of social networks in the place of origin to be driving factors for the return of displaced households. Vulnerable groups that faced traumatic experiences before displacement or that belong to ethnic minorities are less inclined to return. This

${ }^{12}$ See Verwimp (2003a) for a description of the survey. 
is one of the few surveys available that trace the movements of displaced people. The setback is that information was collected only if people requested assistance from the church, which may present some selection bias. This valuable information has been used successfully to examine the extent of asset losses and labour market prospects of displaced people (Ibáñez and Moya 2009), the determinants of displacement (Engel and Ibáñez 2007) and labour supply outcomes and wage changes for IDPs (Calderón and Ibáñez 2009). Czaika and Kis-Katos (Czaika and Kis-Katos 2009) study the determinants of displacement in Aceh, Indonesia using a community-level census, the Village Potential Statistics (PODES), which maps conflict-affected villages across all of Indonesia.

A recent contribution is the Northern Uganda Livelihood Survey (NULS) collected in 2007 as a follow-up to the 2005 Northern Uganda Internally Displaced Persons Profiling Study and the 2006 Lira District Early Recovery Needs Assessments conducted by Fafo, Institute for Applied Social Science (Norway). This household and individual questionnaire covers multiple topics around livelihood choices of displaced populations (Bjørkhaug, Bøås, Hatløy et al. 2008). The questions are carefully phrased and answer categories are specific enough to estimate past experiences of violence such as violent ways of going missing; type of crime and violence experienced; information on the perpetrators; causes of health problems due to combat operations, additionally specifying whether the person was a combatant, and to whom they would turn for protection. Some questions and answer categories from the NULS where guiding us in the development of the module proposed in this paper.

\section{Post-Conflict Reconstruction Surveys}

There are limited examples of surveys implemented in the post-conflict period to assess the sustainability of reconstruction policies. One example is that reported in Mvukiyehe and Samii (2008/9), which evaluates the impact of peacekeeping operations in Cote d'Ivoire. Such surveys have the advantage of being able to capture the potential for conflict re-escalation, as well as perceptions of security amongst populations and repeated violence against civilians in different locations. For instance, the Cote d'Ivoire survey asks explicitly to report on events and circumstances associated with the possibility of renewed conflict. Referring to time periods of at least two out of four given key events, the people were asked whether or not they witnessed or suspected "inter-ethnic fighting, presence of armed groups, or recruitment by armed groups in their localities" (2008/9: 8 ). Other surveys develop instruments to capture the attitudes towards the legitimacy of using violence ranging from 'Nothing can justify the use of Violence' to 'Resort to violence if one's concerns 
are not addressed' (TUUNGANE, survey in the Democratic Republic of Congo 2007, see Humphreys (2008)).

\section{Standardized Conflict Surveys}

Partly motivated by the wish to assess the perception of its interventions, the International Committee of the Red Cross and the Greenberg Research team conduct People on War Surveys for a variety of conflict-affected countries. ${ }^{13}$ The surveys are standardized for all participating countries so that results can be compared across countries. To account for country-specific contexts, the wording of some questions was modified where necessary. In Haiti, for example, the questionnaire asked about 'armed violence' instead of 'armed conflict' (International Committee of the Red Cross 2009).

\section{Summary}

The empirical approaches discussed above have led to wider availability of valuable evidence on conflict processes, as well as the accumulation of expertise on how to conduct rigorous empirical research in contexts of extreme insecurity. Overall, these quantitative surveys are large in scale (interviews lasting for several hours), costly (e.g. NULS), and reflect high level of local expertise. Empirical instruments used to assess the impacts of violence cover different aspect of violence and changes in individual and household situations over time. Some issues have received more attention in the surveys outlined recruitment, reintegration and reconstruction - while others - coping strategies, adaptation behaviour and dynamic social, economic and political interactions have been covered in more limited ways.

\subsection{Use of Existing Socio-Economic Surveys}

The second direction followed by empirical researchers to better understand micro-level conflict dynamics has been to use socio-economic datasets in conflict-affected regions that were not explicitly collected for the analysis of processes or consequences of violent conflict per se, but that can be used for that purpose by being creatively merged with conflict event data.

The main challenge in this kind of work is that conflict and violence are mainly considered as shocks (the civil war taking place in between two survey years), and less as processes. Processes are notoriously difficult to capture in

\footnotetext{
${ }^{13}$ Afghanistan; Colombia; Democratic Republic of the Congo; Georgia; Haiti; Lebanon; Liberia and the Philippines.
} 
standardized household questionnaires unless specific temporal questions can be included.

\section{Standardized Household Surveys and Socio-Economic Panels}

Deininger (2003) conducted one of the first micro-level analyses on violent conflict and its consequences using data on communities and households from the 1999/2000 Uganda National Household Survey (UNHS) and the 1992 Uganda Integrated Household Survey (IHS). These surveys contain information on approximately 10,000 households and 1,000 communities. Though not being purposively designed, the surveys contained questions relating to civil war, which made possible to investigate patterns of victimization and the determinants of participation in the war. The UNHS asks retrospectively whether the household "production of crops/ cattle or livestock rearing/ trading activities has been harmed by the civil strife"; how many incidents "of theft of property" and "of physical attacks on members of the household". The surveys do not however provide precise information about the magnitude of damage inflicted on the household or the severity of violence experienced in specific locations, therefore limiting the scope to differentiate between the legacy of violence amongst different areas and populations.

In 2007, a research team from Antwerp, Brussels, Wageningen University and the National Institute of Statistics and Economic Studies in Burundi (Isteebu) organised a panel survey in Burundi (Bundervoet, Nillesen, Verwimp et al. 2009). The Burundi Priority Household Panel (1998-2007) is one of the few panel data sets in Africa. The purpose of this survey was to analyse the welfare-effects of civil war by comparing households in villages affected by the war with households in non-affected areas. The survey features questions on violence and conflict at the individual, household and community levels. Due to the panel nature of the data, household welfare is measured before as well as after the event of violence in communities. Special attention was given to the tracking of household members who left the household since the first wave of the survey ("split-off households"), see (Verwimp and Bundervoet 2009).

The same team made use of information on violence at the level of the village, the household and the individual to organise in 2009 experimental economic games in war-affected and non-affected areas. The objective of the experiments was to analyse whether exposure to violence affects individual risk attitudes and social and time preferences, see (Voors, Nillesen, Verwimp, et al. 2009). This set-up allows the researchers to link outcomes measured in the survey with those observed in the game. An important difference between survey and experimental games is that the latter cannot be done by a large team. Even very small differences in explaining the purpose of the game can 
lead to different results. While we recommend small teams even in survey research, they are a condition sine quo none in experimental games.

Another example of the use of existing surveys is the resort to historical data. Akbulut-Yuksel's (2009) shows how a unique data-set on city-level destruction in Germany caused by Allied Air Forces bombing during WWII can provide far-reaching insights when combined with a Socio-Economic Panel. While his data-set is much less informative than the one used by Kalyvas and Kocher (2009) in capturing only the effects of city-level destructions, AkbulutYuksel's results suggest that war and violence can have far-reaching impacts on human capital decades after their occurrence.

\section{Demographic and Health Surveys}

The Demographic and Health Surveys (DHS) ${ }^{14}$ do not generally contain information on conflict and violence even if they were conducted in conflictaffected countries. However, these surveys incorporate great detail on health, fertility and mortality outcomes for a variety of population types. The DHS have been used to assess the long-term impacts of genocides. De Walque and Verwimp (2010) used the Rwandan DHS to infer the socio-economic and demographic profile of excess mortality in the 1994 genocide. One challenge of this type of research is to account for the fact that whole families might have died and that families with many survivors might have been over-sampled. Despite the limitations, the authors were able to capture the disproportional negative effect of the genocide on educated and urban groups. These results were similar to the patterns found by De Walque (2004), who used the DHS to assess the long-term impacts of the Cambodian genocide during the Khmer Rouge period.

The United Nations Population Fund (UNFPA) demographic survey collected in Burundi in 2002 is another example of surveys designed to understand health and demographic outcomes. Bundervoet (2009) investigated the profiles of victims of the 1993 killings in Burundi using this survey. The questionnaire contains several questions on child, spouse and parental mortality. The questionnaire has three additional interesting features (i) it contains information on the years (and sometimes month) of the event registered (for example the dead of one's husband); (ii) it records a pre-conflict wealth variable to wit the number of cattle the household possessed right before the conflict and (iii) it includes a section on migration where the household is asked to detail the duration and location of all migratory moves and residences since the start of the civil war. This allows the tracing of the

\footnotetext{
${ }^{14}$ e.g. DHS Colombia 1995; other surveys on this topic: World Health Survey, Micro-level National Family Health Survey (NFHS-III)
} 
whereabouts of the household over time and as such the dynamics of the conflict. We have drawn on these variables in our module below.

Another useful demographic survey is the 2002 Rwandan Rural Labour and Death Survey. This survey asked 1,500 households about changes in the composition of the household in the four years prior to the interview. Among the response categories we find 'murder ', but there are no further questions about the profile of the perpetrators. This questionnaire was not designed as a conflict questionnaire (in contrast to the DRQ), but can be used to analyse the effect of death and disease on household labour supply. ${ }^{15}$

\section{Livelihood and Well-Being Surveys}

Micro-level empirical research on the effects of conflict and violence has made use of the various Living Standard Measurement Surveys (LSMS) implemented by the World Bank since 1980s.

In this section, we review the Living Standards Measurement Study (LSMS) surveys that have included conflict-related questions. We analysed the structure and the contents of 18 questionnaires that have been conducted at different levels in the following conflict regions: Azerbaijan (1995), four waves in Bosnia \& Herzegovina (2001-2004), Guatemala (2000), Iraq (2006), Kosovo (2000), Nepal (1995/96 and 2003/4), two waves in Peru (1991, 1994), Serbia (2002), Tajikistan (1999), Timor-Leste (2001) and Malawi (2004). ${ }^{16}$

The primary objective of these surveys has been to provide high quality data to policy makers to assess the effectiveness of interventions designed to improve the living standards of individuals, households and communities in developing countries and understand their behaviour and choices. In a few cases, the LSMS incorporate questions on experiences with conflict and violence. Bhaumik, Gang, and Yun (2005) have used the Kosovo LSMS to analyse the relationship between ethnic conflict and economic disparity between Serbians and Albanians in Kosovo (see also Bhaumik, Gang and Yun (2008)). Alva, Murrugarra and Paci (2002) make use of the Kosovo LSMS from 2000 to analyse the 'hidden costs' of ethnic conflict by decomposing trends in educational outcomes.

\footnotetext{
${ }^{15}$ Evidence for the estimation of war deaths, which is not the focus here, is collected in so-called mortality surveys. See for the discussion of their quality Degomme and Guha-Sapir (2007).

${ }^{16}$ For an excellent description on the development, changes and experiences with LSMS refer to Deaton (2000: 32-40). In April 2010, the Social Development Department at the World Bank produced the Datasets on Violence including three global datasets at the country level on the following types of data on violence: (a) Violent Conflict; (b) Homicide Rate; (c) Domestic Violence. These user-friendly datasets rely on web-based secondary sources (UCDP/PRIO, WHO, UN, DHS among others). You can access the Datasets on Violence at http://go.worldbank.org/NRVI5T44Y0.
} 
Individual and household data from the 1999 and 2003 Tajik LSMS have been used to analyse the effects of conflict on female education enrolment and attainment (Shemyakina 2006), on labour supply and migration (Justino and Shemyakina 2008) and on marriage and reproductive behaviour (Shemyakina 2009).

Kondylis (2007) studies the effects of conflict-induced displacement on labour market outcomes in Bosnia and Herzegovina using the 2001 LSMS and Swee (2009) uses the Bosnian LSMS (2001-2004) to analyse war and schooling attainment. Information on the mental health status of nearly 7000 individuals from the same 2001 survey of whom approximately 63 percent were reinterviewed in 2004 was decisive for the study by Do and Iyer (2009). They find no significant differences in overall mental health across people who experienced different levels of exposure to the conflict. They also emphasize the problem with the current scarcity of data on mental health measures that could be overcome with extension of the LSMS.

Using the pre-war (1995/6) and post-war (2003/4) LSMS Hatlebakk (2007) analyses Maoist influence on data-collection quality in Nepal, finding only minor impacts such as the need of approval for data-collection (see also on Nepal: Jacoby (2000), Bardhan, Baland, Das, et al. (2002), Bohara, Mitchell and Nepal (2006); Koolwal (2007) and work by Samii, Gilligan and Eck (2009) on Nepal; and on Peru Ilahi (2001)).

The LSMS and other socio-economic surveys are not designed to estimate the impacts and roots of violence. Therefore, several issues demand careful attention when make use of these datasets in conflict analysis. First, we need to keep in mind that the primary objective of these surveys is to provide quality data to policy makers to assess the effectiveness of policies and interventions aimed at improving living standards in developing countries. In conflictaffected countries, the questionnaires end up therefore focusing on experiences and the evaluation of living standards after - rather than during - the conflict (e.g. Kosovo 2000 or Bosnia and Herzegovina 2001-2004). Secondly, most of these surveys are designed in close cooperation with governments and attempt to meet their specific needs. Therefore, many conflict-related questions may be considered too sensitive and are in general missing from such surveys. Thirdly, questions with conflict-related elements tend to be spread in different parts of the survey and in most cases lack follow-up questions that might further inform on the extent of harm caused by specific violent events or their timing. Fourthly, LSMS surveys and other general socio-economic surveys lacks comprehensiveness to cover different dimensions of conflict. Even if relevant topics are discussed (e.g. displacement, health, education), they rarely link the these specific experiences to the conflict. Thus, neither is the scope of questions covering conflict and violence nor the scope of the usually broadly defined answer categories comprehensive. For instance, in her study on displacement, 
Kondylis (2007) faced the problem of not being able to differentiate between refugees and internally displaced people. Consequently, many relevant experiences might be absorbed in the answer category 'others', which cannot be used for final analyses. Finally, only few surveys are comparable (e.g. LSMS in Azerbaijan and Tajikistan) as differences in wording of the questions and the time period referred to (ex-ante, ex-post or during conflict) make the comparability of results over countries very difficult. While the purposively designed surveys reviewed in the section above were in some cases too focused on particular experiences during and after the conflict, general purpose surveys are not enough focused on conflict processes.

In order to ensure the comparability of findings across different countries with these types of surveys we need to be able to better conceptualize violent conflict at the micro-level, make data collection more systematic and design ways of ensuring comparability of findings across population groups, countries and time. In section 4, we propose a series of instruments that will go some way in addressing some of the shortcomings of existing empirical surveys in conflict affected areas and countries. Before that we discuss below some of the challenges involved in designing systematic comparable instruments to capture conflict processes in micro-level surveys.

\section{Methodology: Designing and Contextualizing a Generic Violent Conflict Module}

Research in conflict-affected areas takes place under unusual and often insecure circumstances. Data gathering in conflict-affected areas is problematic due to obvious reasons, like the danger posed by the environment itself, and restricted opportunities to access survey respondents. For instance, Arjona and Kalyvas (2008) report several interruptions in their interviews with excombatants in Colombia due to security reasons and logistic problems, which exposed the researchers to repeated needs for improvisation (see also Kalyvas and Kocher (2009); Restrepo, Spagat and Vargas (2004)). In addition, infrastructure is generally poor and researchers may experience difficulties in accessing many communities of interest. For instance, access to areas and to certain individuals and households may be dependent on complex negotiations with state and non-state actors. Therefore, biases in the choices of survey participants can occur due to political constraints and sensitivities. In this section, we discuss further challenges we face in designing and implementing micro-level questionnaires in conflict-affected areas and amongst populations exposed to - often persistent - levels of violence. 


\subsection{Defining and Measuring Key Terms: General and Context-Specific}

We start this section with a discussion of key terms used in conflict analysis in the policy and academic literatures, and explain how we apply these concepts to the development of the conflict identification module. This is important in order to enable fieldwork researchers to accurately understand, ask, adapt and explain the questions proposed in the next section. Clear definitions will also allow for more precise interpretations of the results obtained from the surveys. The section focuses on the following issues: the concept of violent conflict and how to operationalize it in micro-level surveys, appropriate units of analysis, time dimensions in which to track both shocks and processes of violent conflict.

\subsubsection{The Concept of Violent Conflict}

Existing typologies of violent conflict are not very informative when trying to interpret or operationalize them from individual and group perspectives. Several authors have proposed more or less overlapping typologies of violent conflict, which include notions of violence against citizens, civil wars, guerrilla wars, coups, revolutions and riot. They have differentiated by participants and non-participants (Gupta 1990), between interstate wars, internal and civil wars Singer and Small (1994), between conventional, irregular, and symmetric nonconventional warfare (Münkler 2005; Kalyvas 2006), ethnic and non-ethnic wars (Sambanis 2001) ${ }^{17}$. These typologies are, however, difficult to uphold at the micro level when, for instance, a civil war or a revolution may be difficult to distinguish from other forms of individual or group-based violence for the affected individual, or from other types of shocks. Another difficulty has to do with understanding when violent conflict starts or ends from the perspective of individuals and households. The Armed Conflict Termination Dataset, for example, uses a dummy that records whether the conflict is terminated with the requirement of at least one year on non-activity (Kreutz 2005). This definition however does not take into account small-scale temporal or geographical changes that may vary across locations, the persistence of lower levels of violence and instability that may continue to affect households and their members or changes in the identity of the belligerents. Most individuals and groups living in conflict-affected areas often find themselves responding, acting and being affected by stages in between conflict and peace. Therefore, the inability to capture these nuanced phases of conflict may affect our understanding of how different people and different areas may be affected by violent conflict at its various stages.

The changing and varying nature of conflicts and violence make it necessary to capture the various aspects of conflicts while at the same time

\footnotetext{
${ }^{17}$ See Vasquez and Valerino (2010) for a review of existing typologies.
} 
establishing simple definitions that can be easily captured through empirical data collection. In its most simple understanding, 'conflict' can be defined as a fundamental disagreement between at least two actors on some issue of common concern. Examples of conflict may include price negotiations or legal disputes. Contrary to many government-centred definitions of conflicts (UCDP/PRIO (2007) ${ }^{18}$, HIIK until 1991), the state does not have to be a participant in these types of conflict. Violent conflict occurs when parties in disagreement resort to the use of force. The nature of the use of force may vary across types of conflict such as political violence, random violence, ethic violence, and ordinary crime is necessary (Fearon and Laitin 2003; Davenport and Stam 2009; Verpoorten 2010). Kalyvas' and Kocher's (2009) findings on insurgent selective violence and incumbent indiscriminate violence show, among others, that disaggregated measures of violence "are essential for understanding the violence of civil wars". Thus, while one can define 'violence' simply as use of force, there is a need to differentiate different levels of intensity. The HIIK's Conflict Barometer and the conflict database COSIMO/CONIS, ${ }^{19}$ for example, distinguish between different levels of intensity of violent conflicts at the macro-level including 'sporadic violence' by one of the parties, violence repeatedly used in an organized way by forces, and situations where "violent force is used with a certain continuity in an organized and systematic way" and where the conflict parties would exercise "extensive measures, depending on the situation" with massive and long-term destructions (http://hiik.de).

Household- and individual surveys could complete these definitions by identifying more precisely types of violence, whether it is physical, sexual, verbal, or psychological, as well as in which context it is taking place (home, community, battle field).

\subsubsection{Units of Analysis}

The unit of analysis on which survey data is collected is an important concern (for the discussion of methodology in practice (Green and Tony 2008; Verwimp and Bundervoet (2009); Bundervoet, Nillesen, Verwimp et al. 2009). At the lowest level of analysis is the individual. Concentrating on the individual level allows us to account for intra-household issues and assess the impact of individual shocks such as death, disability, disease, dislocation, and destruction. It also captures personal activities, outcomes, expectations: For instance the Timor-Leste (2001) LSMS survey asks for information on: 'How did you live two

\footnotetext{
18 The Uppsala Conflict Data Program defines 'armed conflict' as a "contested incompatibility that concerns government and/or territory where the use of armed force between two parties, of which at least one is the government of a state, results in at least 25 battle-related deaths" (UCDP/PRIO (2007)).

${ }^{19}$ see: http://hiik.de/en/methodik/index.html
} 
years ago, before the violence in 1999, compared to how you live today?' and 'What has improved since the violence in 1999?'. Individual level approaches also enable researchers to gather information on group identification (for example ethnicity) or trust in others. The objective of using individual-level questions is therefore to determine how individual decision making - across gender, age and different socio-economic backgrounds - responds to the impact of violence on livelihoods, wellbeing and security. This will also allow the surveys to capture specific individuals that may have been directly involved in the conflict, for example as soldiers, refugees, displaced people and so forth.

At the household-level, the head or another member of household responds on behalf of the household ${ }^{20}$. Household-level questions give the opportunity to assess the impact of shocks on the households as a unit of decision, such as access to services and markets, investments, land access and use. Household-level questions can also be used to draw broader pictures about social relations and networks. Instead of asking every household member a question on harm inflicted directly, it can be more appropriate to ask it more generally for the whole household: "Was any member of your household injured or disabled during the war or when you were leaving your previous home?" (LSMS Azerbaijan 1995) The standard household survey is useful as an instrument to capture violence and conflict when the latter are relatively widely distributed in the population.

Because violent conflict events can be very concentrated in time and space, in some circumstances, community-level questions may be more appropriate to uncover the extent of the impact of violent conflict. Communitylevel analysis when violent events affect whole communities will allow for more accurate determination of deaths across the community (for instance by examining listings of names using local administrative records). Moreover, knowledgeable members of affected communities can provide important qualitative and quantitative insights. Community-level surveys are also especially useful in the assessment of migration flows, of urgent needs of the community and on the impact of policy interventions (particularly reconstruction interventions in the post-conflict period). Overall, communitylevel surveys can be used as starting points for the design of household surveys as they allow the construction of overall characteristics of localized events.

The core units of analysis we focus in this paper are the individual and the household. Violent conflicts are generally a collective process and are rarely based on individual actions. However, groups do not constitute uniform entities but are rather formed by interactions at several cultural, social, political and economic levels of different individuals and/or their families driven by common (but not necessarily equal) interests and aspirations. In the

\footnotetext{
${ }^{20}$ We refer to households as "a group of non-state actors that share common living standards" (Justino 2009: 317).
} 
development of the conflict identification module, we are particularly concerned with understanding the political, social, economic and cultural processes and norms of interaction between individuals, households and groups that are affected, but may also impact, on processes of violent conflict.

\subsubsection{Time dimensions}

The timing of surveys in conflict-affected countries is decisive for the quality of information and the ability to trace the impacts of the conflict. Three main approaches have been used to date.

Firstly, if the violent conflict is still ongoing at the time of the survey, researchers tend to use a 12-month reference period to elicit information on conflict experiences at the level of individuals and households. In this way, researchers are able to grasp relatively short-term effects of violent conflict on household members. When the conflict has ended more then a year ago however, it does not seem useful to use this short-period reference as there would be a danger to exclusively refer to the post-conflict situation rather than to the experiences during the war.

Secondly, acknowledging the fact that most conflict events cannot be measured contemporaneously, researchers have aimed to address the issue of temporal comparison of living standards before and after the conflict in the questions by asking direct questions related to individual and household characteristics before and after specific events. Many questions asked in the LSMS interviews, for example, address the problems of missing ex-ante data by regularly using phrases such as "before the conflict", or "since the start of the conflict'. Ex post measurement can of course suffer from severe recall error and attrition. The length of the recall period has been a topic of discussion in socioeconomic, demographic and epidemiological surveys for a long time (Deaton 2001). For instance, LSMS questions on conflict often ask for information long after the conflicts ended. The situation of the households and individuals in Serbia has been for the first time investigated seven years after the official end of war (six years in Bosnia and Herzegovina; five years in Iraq). Thus, the shortterms effects of the war on Serbian households will never be known. The same holds true for the economic, social and political trajectories followed by these households to recover from the conflict. For the analysis of such trajectories, researchers would need to access information right after the conflict and then again some years later.

In conflict situations recall issues may be minimized by the violence itself. When violence takes on serious forms, such as the death of a household member or the loss of livestock, surviving household members will generally remember fairly accurately the situation due to the devastating effect of the event. For very long recall periods, it is common practice to use timelines 
depicting major, nationwide historical events that are useful to help households situate violent events that happened to them.

Most of these difficulties are minimized if panel data is available as panel studies allow researchers to trace the dynamics of conflict over time. Of course in tracing households and individuals over time in conflict-affected areas, researchers have to address the fact that samples will include people that are very mobile. Changes in these samples must be carefully traced. Additionally, one has to consider the fact that people or entire households might have been killed in violent conflict. Neglecting to re-interview household members who moved (for example marriage, work related migration, etc.) in between the two waves of the survey may lead to biased estimates. Beegle, De Weerdt and Dercon (2008) and Bundervoet, Verwimp, and Akresh (2009) have shown this to be the case for poverty estimates for Tanzania and Burundi respectively. In the absence of tracking, inferences on the effects of violence may be biased when the violence causes household members to leave the parental households.

\subsection{Comprehensiveness and Ethics}

In designing a general module to be included into other surveys we face a trade-off between comprehensiveness and length of the questionnaire. One of the keys to successful questionnaire design is to limit the number of questions, not only because often only few of them are actually used in the final analysis, but also to limit the length of the interview. Surveys where the questionnaire is too long, questions are too difficult to answer, or that are too time-consuming, may result in high non-response rates, which would undermine the validity of the data generated (WHO 2004: 19).

The need to limit the module to only necessary questions is also derived from the consideration of ethics and moral restraint to inflict harm to the respondents when asking about their experiences with violent conflict.

The module may also involve the analysis, compilation and collection of potentially sensitive data that may affect the privacy of subjects being interviewed, for example when questions invoke harmful memories about war crimes such as rape.

Several direct and indirect mechanisms have been proved useful to address and minimize potential ethical risks. Generally, it is useful to always question whether specific research questions are necessary and whether there are other ways of obtaining the same information that will minimize harm. It should additionally be ensured that the interviews only take place when full and informed consent of the participants is obtained (e.g. through signed consent forms when viable and appropriate or through verbal consent).

A further instrument to circumvent direct references to traumatic experiences is to pose the questions in nuanced ways. Seemingly unrelated 
follow-up questions, for example, can reveal important information in a logical chain of questions. Conflict-related questions can be addressed directly. „Was any member of your household injured or disabled during the war or when you were leaving your previous home?". Yet, in some cases it might be helpful to ask the questions indirectly. Hereby, the given answers to the question "Do you know what happened to [NAME]?" can contain information on the experiences during the conflict in one of the answer categories. In fact, the right answer types can provide guidance through difficult parts of the questionnaire. They can be given in three different ways, namely the answer choice very implicitly refers to the conflict situation by 'others'; is explicitly given ("How would you describe your disability? - War wounded"), or is not specified at all in case of open questions ("And what would you say are the three principle causes of poverty?"; "When did the majority of refugees and displaced persons arrive in this population point?" $).{ }^{21}$ However, instead of conjecturing about the channels and impacts of violence and conflict, when the researcher beliefs that violence impacts the household one way or the other, it is better list all potential mechanisms in the questionnaire. If not, many responses will be registered as 'other', which, once the survey is done, will be a black box.

Last but not least, the module should avoid posing questions that could threat the security of respondents and interviewers. Indeed, one of the difficulties of conflict and violence questions in household surveys has to do with uncovering the identity of the perpetrator. Even when the information is known, the respondent may not want to reveal it. To limit harm, it is generally of better practice to ask about group behaviour rather than asking for specific names of perpetrators.

${ }^{21}$ Most of the questions referred to have been collected from various LSMS questionnaires. 


\section{The Module}

The section explains the approach, structure and choice of questions in the generic module. Therefore the general module is decomposed into different topics, which will be discussed individually. Our focus is thereby on the impact of violent conflict on the households' livelihood. In the first section we aim to identify changes in the household-composition (4.1.) and changes in the economic welfare (4.2.), distinguishing between changes in income (4.2.1.) and assets (4.2.2.). After identifying this background information, we more closely look at changes activities (4.3.), the impacts of conflict on health (4.4.), displacement (4.5.) and education (4.6.). We conclude with a section on perceptions of security (4.7).

\subsection{Section A: Changes in Demographic Characteristics}

Understandably, people fear death and separation of their family members (ICRC 2009). Indeed, both outcomes can lead to long-term impacts on the household and individual welfare. The module begins with identifying changes in the household composition (A1, names of the household members). Additionally, we consider an often-neglected outcome of conflicts, notably the changing composition of households.

Psychological trauma, low family connectedness, abduction and orphanage predict poor labour market success (Annan, Blattman and Horton 2006). Additionally, depending on the characteristics of the members who leave or join, this may lead to changes in productivity and income. It can also lead to assets and human capital losses, especially if child labour is used to replace the gap and surviving members need to draw on existing savings (Justino 2009; Rodriguez and Sanchez 2009).

Thus, the clarification of the age of the person who left or joined can be an indicator for whether the share of people at working age in the household decrease or increased (A2, date of birth). Acquiring information on orphans and child-headed households will allow users of the survey to categorise and, in later stages, target vulnerable individuals (Annan, Blattman and Horton 2006) 2006).

Questions on the gender of all household members (A2, sex) are not only standard in household surveys but also help to identify gender-specific vulnerabilities. Some evidence suggests that a re-allocation of tasks takes not only place across age but also gender, with women, especially widows, driven to take over new roles (for example as income-earners), become the new household head, and perform productive activities that are confined to men 
during times of peace (El-Bushra 2003; Schindler 2008; Annan, Blattman, Mazurana et al. 2009; Brück and Schindler 2009b). ${ }^{22}$

\section{A1: Reason why [NAME] has left the household.}

The reasons why a person left the household can provide the first direct information on the impacts of war. Violent conflicts can lead to massive disappearance of people, internal displacement, (forced) recruitment, and hostage-taking. Yet, the instruments to measure these reasons are often missing in many relevant surveys (see e.g. NULS 2007 as a good example). In the module proposed, this question is the first instrument used for the analysis of processes of population movements caused by conflicts due to destruction, violence, insecurity, and threats. Answers to this question may also reveal information on early responses to conflicts, such as leaving for 'political reasons', and more about direct contributors for the onset and duration of the conflict, such as recruitment, imprisonment, or abduction. Unfortunately, it is not possible to differentiate between 'normal' recruitment and involuntary recruitment in the LSMS surveys. Some LSMS surveys ask whether the person has been absent due to 'military service (LSMS Serbia 2002; LSMS Tajikistan 1999). However, these surveys are not informative on whether recruitment was voluntary or not. Furthermore, information about political discontent and political imprisonments is seldom collected (for an example of this type of questions see Afrobarometer).

We additionally ask for the timing of these changes in the household composition (A8), which might reveal information on dynamics of the conflict people acting differently in different phases of the conflict. Additional questions on the age of people leaving the household (A9) might be interesting for the analysis of the strategies of the warring parties to recruit or abduct people (Annan, Blattman and Horton 2006).

It is also important to give respondents the opportunity to reveal additional information not necessarily related to the conflict, such as 'marriage', and 'left for work'. This information will serve to assess the relative importance of conflict-related household events, but can also be used to analyse indirectly some conflict-related outcomes. For instance, increased occurrence of marriages might be indirectly linked to conflict as a strategy of responding to a lack of protection and educational opportunities. For instance, Annan, Blattman, Mazurana and Carlson (2009) have recently shown how even the rebel groups themselves might use forced marriages to enhance control of the forces and as an instrument of protection against HIV.

\footnotetext{
${ }^{22}$ Questions on members of the household that joined or left because of the conflict can be posed at the beginning of the questionnaire - directly in the household roster - or, as we suggest, additionally in the conflict module (A1) where the answers can allow researchers to double-check previously given information.
} 


\section{A2: In case [NAME] died, what was the cause of death?}

As we discussed in previous sections, the objective of the module is not to provide estimates on death tolls but rather to uncover their causes. We have therefore designed this question with several answer categories that will allow survey users to understand more precisely when and under which circumstances deaths in the household are related to violent conflict. Some existing surveys already contain similar information, albeit in more limited forms. The DRQ 2007 includes 'murder' (DRQ 2007) as part of the answer categories on the question why somebody is not a member of the household anymore. The LSMS Timor-Leste 2001 asks whether the person 'died in violence' and 'died, not in violence'. However, if the person died due to violence, it will be informative for the estimation of the causes and consequences of conflict to distinguish between deaths that took place due to armed or non-armed violence. This would allow survey users to estimate more precisely the consequences of violent conflict on household mortality and separate those from other violent events such as crime, or gang activities, which are also prevalent in conflict settings.

The identification of the reason of death can also be indirectly connected to vulnerability of other household members to illness, blame, and isolation. Conflicts are linked to higher likelihood of suffering, or even dying, from diseases and malnutrition. The linkage exists due to the loss of shelter, the inability to reach hospitals due to infrastructural destruction, the collapse of the insurance systems, the sanitation, and the safe water supplies, as well as the spread of infectious diseases (Nathanson 2000; Guerrero-Serdán 2009; International Committee of the Red Cross 2009) and lack of appropriate nutrition (Bundervoet, Verwimp and Akresh 2009).

\section{A3: Reason why [NAME] joined the household.}

Reasons for joining households are often neglected in existing surveys. Yet, where on the one hand some household might loose members due to conflict, others might welcome new members. The collection of information on new household members can reveal information on the impacts of conflict even if it took place in distant regions.

One reason might be the increased need of protection as a consequence of conflict. SWAY's household questionnaire, for example, asks directly whether orphans have "come to live with you because they have lost their other family". People might also be in search of protection for other reasons than the loss of their family members, notably the destruction of their houses or loss of key assets. 


\subsection{Section B: Economic Welfare}

This section discusses possible ways of recording the impact of violent conflict on household's economic welfare, in particular in identifying changes in income situations (part 1) and asset endowments (part 2). This will enable module users to investigate whether and to what extent the conflict may represent an economic shock to the household.

\subsubsection{Income}

We start the section by identifying groups of people that may have experienced severe losses of income due to conflict (B 1.1), the duration of this interruption (B 1.2.), and the reasons for the losses (B 1.3).

B 1.1: Did you experience severe losses of income since the outset of the conflict [SPECIFY PERIOD OF TIME IN CONTEXT]?

$B$ 1.2: What was the longest period of interruption?

B 1.3: We would like to specify the reasons for the losses of income. Did you experience any of the following?

Conflict and violence can directly and indirectly affect the ability of households to generate income (Ibáñez and Moya 2009; Justino 2009). To identify dynamics of these impacts it is important that people can record several reasons for experienced losses and directly link them to the timing of the changes experienced.

With non-purposively designed questionnaires it is difficult to gain a broad picture about household difficulties to generate income in the context of conflict and violence. While relevant aspects have been considered in some surveys, it is difficult to find them all in one questionnaire, or one module (relevant questions are usually spread across modules on labour, finance and agriculture). Overall, while LSMS surveys, for example, capture employment and income questions in different parts of their modules on labour, finance and agriculture, ${ }^{23}$ we collect this information in a sequential form.

\section{Lack of Employment Opportunities}

Destroying the enemy's economic strength is one possible strategy to wage war. This strategy can explicitly or implicitly target civilians when enterprises close ${ }^{24}$

\footnotetext{
${ }^{23}$ In other places, surveys particularly investigate whether a person was employed in 'military or police' e.g. by clarifying the person's insurance and the pension schemes (Peru 1994) or by asking directly for the 'sector' of employment (Tajikistan survey 1999 gives the option 'Public Administration \& defence'). The person's business or job activity could also be 'connected with' 'army and police' (Serbia 2002) or 'armed forces' (Tajikistan 1999).

${ }^{24}$ For a recent survey of Entrepreneurship and Conflict we refer to Brück and Verwimp (2010), WIDER Working Paper, forthcoming. See also answer category 'Enterprise doesn't work because of war and other difficulties' (LSMS Bosnia-Herzegovina 2002).
} 
and markets collapse. Thus, reductions in income can also be brought about by changes in off-farming employment opportunities.

\section{Security Considerations and Infrastructural Destructions}

Losses from conflict such as decreases in earning capacities can stem indirectly from the inability to sell and buy goods due to difficulties to get to the markets (Justino 2008). Infrastructural destruction and security considerations can limit access to markets, impacting on those who rely on people's exchange activities ('loss of access to input markets'; 'loss of access to output markets'). Moreover, market adjustments may impact on household income status through changes in the market price of goods sold and purchased by the household (Singh, Squire and Strauss 1986). In the module, we ask respondents to self-report on causes of income loss such as loss of assets, payments to warring groups and physical insecurity ('vandalism or crime in the area', 'landmines/ security'). In later sections, the module will develop these issues in more detail. Insecurity and interruption of work have been investigated and linked in existing surveys such as the LSMS Iraq 2006, which asks reasons for why respondents did not work 'even for an hour, during the last 7 days?' One of the answer categories is 'due to security situation'. We build on these types of questions and tried to design more nuanced answer categories in order to capture different aspects of living with violence in conflict affected areas.

\section{Military Service}

The interruption of work due to military service can lead to setbacks in terms of earning and productivity capacity. ${ }^{25}$ On the other hand, it can also be part of coping strategies followed by people to protect themselves and their families economically and physically (Annan, Blattman and Horton 2006; Justino 2009). Apart from direct impacts on income, recruitment can indirectly impact on the productivity through a lack of manpower to perform necessary work. We include this answer category in order to enable survey users to capture these important effects of violent conflict on individuals and households.

\section{Restrictions on Investments}

The inability to invest in future production can stem from losses of savings, the inability to access credit markets, and the disappearance of informal risksharing networks (Justino 2008; 2009) So far it has been difficult to evaluate changes in the access to credit markets during and after violent conflict due to the lack of appropriate data. This has partly to do with the fact that most existing surveys in conflict-affected countries focus on post-conflict reconstruction rather than surveying economic dynamics during the conflict.

\footnotetext{
${ }^{25}$ In the LSMS in Bosnia-Herzegovina (2001-2004) the respondents could reply directly whether they 'stopped working' due to 'military service' (another option was 'displaced').
} 
To the best of our knowledge, the only survey where the information may provide insights about the impact of conflict on credit markets in the LSMS Iraq, which asks whether respondents borrowed money due to 'emergencies (illness, injury, fire, flood, theft)'. We have include this option, and extended it, in this module.

Social Restrictions

Another outcome of conflict might be new social restriction aiming to exclude some people from work or access to credit due to their ethnicity or gender (see World Bank 2005). On the question of 'Why don't you want work (or work more)?' Iraqi people could, for example, among others chose not only 'too risky due to security situation' but also 'social restrictions' (LSMS, Iraq 2006). In the Kosovo survey (2000), people can indicate, whether the main reason for loosing the job was 'discrimination for ethnic reasons'. In the module we include 'discrimination' as an answer category on the question for the reasons of income losses.

\section{Set-backs in Health}

Finally, short- and long-term impacts on health can be the result of injuries and psychological distress, both reducing the ability to be productive (e.g. Annan, Blattman, and Horton (2006) on Uganda). We have decided to ask directly whether people associate their losses of income with these setbacks in order to obtain more detailed information on people's own perceptions on losses. Another possibility, that is often used in surveys in conflict-affected countries, is to specify whether respondents or other household members have been injured and how severely. The NULS (2007) for example asks whether the person finds it difficult to go out without the help of others due to a chronic health problem or handicap ('yes, a bit difficult' and 'yes, definitely'). We include this type of questions in the module by relating them specifically to the conflict.

\subsubsection{Assets}

B 2.1: Were any of the following assets considerably destroyed, lost or robbed because of the violence or displacement?

B 2.2: When exactly did this occur?

B 2.3: What was the overall value of the item at the time that it was lost? (SPECIFY CURRENCY)

B 2.4: Who was responsible for the destruction or theft? (SPECIFY IN CONTEXT)

Assets are important mechanisms of self-insurance in risky environments and at the same time likely to be destroyed in heavy fighting as well as to become key targets for soldiers and looters (Brück (2004: 9), (Bundervoet, Verwimp and 
Akresh 2009; Justino 2009). Jewellery is a case in point. The value of assets may also change considerably in conflict contexts, hence exposing people to greater vulnerability. Certain assets play important roles in protecting and sheltering needs. Therefore answer categories for B 2.1 include: 'dwelling'; 'shelter material'; 'clothes'; 'blankets', 'mattress', 'rifle/ machete'. Typically, existing surveys consider solely the destruction of dwellings, with hardly any information being provided on other assets that may be important for the household. 26

Indeed, conflict-related destruction or damage of dwellings affect people in many severe ways as it is not only linked with reductions in economic and physical security but is also typically associated with displacement and other forms of forced migration. However, none of the questionnaires we reviewed included questions on losses, destruction or theft of other household assets. But there is very strong evidence that certain assets such as hoes, ploughs, tractors, torches and so forth are important in rural contexts, sometimes as important as dwellings given that livelihoods depend on their possession. The ability of people to be mobile and informed can also become essential for survival and assets such as bicycles, motorcycles, cars radios, TVs and cell phones typically rising in value in contexts of conflict (see Ibáñez and Moya (2009)). In situations of displaced and other types of migration, documents and certificates, such as 'birth certificates', can also become important. In this process, ex-ante wealthier households might loose their economic advantage or economic potential (see Bundervoet, Verwimp and Akresh (2009)), whereas previously poorer households might gain in comparison to the pre-conflict situation (Fiala 2009).

The module proposed allows us to assess conflict related losses of various assets, as well as their value. This may allow module users to estimate more accurately the costs of the conflict, or the potential benefit incurred by those that loot or steal assets. ${ }^{27}$

\subsection{Section C: Activities during Conflict}

How do people adjust to the manifold challenges and incentives that conflicts bring about? Answer categories on coping strategies followed by individuals and households may provide valuable information for policy makers as they will reveal information on the long-term impact of violent conflict for the

\footnotetext{
${ }^{26}$ In sections on 'Institutions and Infrastructure', 'Dwelling' or 'Housing', the LSMS has captured these experiences in a variety of direct and indirect ways. In the context of postconflict reconstruction, the interest hereby lay on the estimation of the extent of destruction to the dwellings ('almost completely destroyed', 'significant damage', 'moderate damage', 'only slight damage' (Timor-Leste 2001; see also Tajikistan 1999, and Bosnia and Herzegovina 20012004).

${ }^{27}$ We assume here that detailed questions about changes in livestock are either included in the agricultural module or in a separate livestock module.
} 
country as a whole (Food and Agriculture Organization 1996). Coping strategies in risky environments can take different forms. These can be ex-ante coping activities when the household has anticipated changes by adjusting their behaviour before the shock has taken place (an example would be the sell of livestock before the conflict). Strategies can take place ex-post, as a reaction to lower (or for certain people higher) levels of opportunities due to insecurity and violence. Unfortunately, coping strategies are seldom a focus in household surveys in conflict affected situations (but see Bozzoli and Brück 2009a and Brück and Schindler 2009a). The only examples we have reviewed include the Mozambique National Agriculture Survey 2005 and the LSMS Iraq 2006. This latter one offers good examples of activities followed by people to 'compensate' for decreases in income and/or in assets. One example is 'begging'. Further research on the identification of coping strategies during and after violent conflict would therefore fill important gaps in the micro-level analysis of the short and long-term impact of violent conflicts. The next sub-sections outline how we have approached the issue of coping strategies in the proposed module.

C1: Have you or your household members changed your economic activities as a result of violence [SPECIFY TIME PERIOD IN CONFLICT]?

C2: Compared to the situation before the conflict [SPECIFY PERIOD OF TIME IN CONTEXT] what changes did you actually make?

Crops and Livestock

In the face of violence, households would tend to change the production portfolios. Brück (2004) describes how coping strategies can become very risky during periods of war thereby reinforcing people's levels of economic vulnerability. War-affected households may also withdraw from markets completely and resort to forms of subsistence agriculture. Equally, while owing livestock may be a profitable and secure economic strategy in peace times, it may become quite risky in wartimes due to the collapse of markets, services or the danger of theft (Bundervoet 2006; Verpoorten 2009). Using data from Burundi, Nillesen and Verwimp (2010) however challenge the idea that farmers resort to subsistence in a post-conflict setting. Detailed and comparable registration of the different types of economic activities before, during and after conflict can help to address this issue in future research.

\section{Consumption and Investments}

One common coping strategy followed by households affected by economic shocks includes the change of diets by decreasing the number and quality of meals, or making used of food storages. Price increases of local food during and in the aftermath of a conflict may contribute to such strategy, which will have detrimental impacts on nutritional outcomes of household members, children in particular (Ghobarah, Huth and Russett 2003; Bundervoet, 
Verwimp and Akresh 2009; Guerrero-Serdán 2009). The may lead to severe long-term losses in human capital (Alderman, Hoddinott and Kinsey 2006). Households may also engage more in sharing food with others. Annan, Blattman and Horton (2006) find for the case of Uganda that that broader family and social connections can be decisive for nutrition, even more important than having immediate family.

Questions related to issues of food security during violent conflict appear in some surveys. For instance, the Mozambique National Agricultural Survey 2005 asks questions - that we borrowed for part of the module - on the number and quality of meals, levels of consumption of stored seeds and the sell of livestock.

\section{Social Interaction and Reliance}

Another common coping strategy is the increase of vulnerable households on transfers and assistance, either from state institutions or more commonly from family and extended social networks (Platteau 1991; International Committee of the Red Cross 1999; 2009). This issue is typically a major focus of postconflict reconstruction surveys and we follow some common ideas in the design of this part of the module.

Violent conflict impacts profoundly levels of engagement of social networks in affected communities and groups. Community norms and relations may improve due to the sheer need for cooperation (Petersen 2001; Miguel and Roland 2006; Fearon, Humphreys and Weinstein 2009) or may be damaged due to the destruction of traditional ties, organisations and habits, disorder, oppression, and betrayal (Kalyvas and Kocher 2007). This may be enforced by increased levels of distrust and violence. The Kosovo LSMS 2001 indirectly addresses this issue in a section on 'business assets', by looking at networks. Several questions are asked on whether and how often members of the household have joined 'other members of [the] community [to] come together to address a common concern' or 'to approach an official (government and/or NGO) for assistance with a common concern'. It also includes questions on how far people rely on assistance (e.g. in case of 'serious illness' or sudden death) on their neighbours, friends, community and/or religious leaders. The proposed module captures also these changes by asking about respondents' engagement in social networks and related these to local conflict events. In addition to common questions, we ask also whether people may decide to share tenancies if, for example, their dwelling was destroyed.

C3: Did you take any of the following steps in/during [SPECIFY PERIOD OF TIME]?

C4: If so, when exactly did you introduce this measure?

$\mathrm{C5}$ : What was the main reason? 
One important issue in understanding conflict dynamics at the individual and household levels has to do with the relationship between civilians and armed groups. This is generally addressed in detail in the ex-combatants surveys we reviewed. However, links between this relationship and socio-economic contexts of civilian households are typically limited in ex-combatant surveys. In the module we include questions on the interaction between household members and combating parties such as instances of household members joining the official police, joining rebel groups or joining the military. We are also interested in going beyond the mobilisation process itself, and also look at other attempts to adjust to new or old rulers such as the payment of contributions to rebel groups, and attempts to bribe governmental officials or rebel groups. We expect this information to advance our understanding about the type of governance that is established by rebel groups or the military during civil conflicts. Moreover, the household may also try to engage in local self-protection, independently of any warring parties by joining or establishing community policing or neighbourhood watching, procuring weapons (handgun, shotgun, rifle, machete, etc.), acquiring guard dogs, employing watchmen, improving house security (bars, walls, fence) or resorting to traditional remedies to increase protection ${ }^{28}$. The inclusion of these types of questions could provide us with important indicators of local political transformation processes, which so far have remained unexplored in the literature (Justino 2009).

In the proposed module, we also ask for the reasons why certain decisions have been made in order to better understand motivations and attitudes to political transformation. The intention behind these questions is to uncover whether people act, as predicted in the greed-grievance debates, out of material interests, out of forms of grievances, emotions or discontent, or as a way of self-protection (Arjona and Kalyvas 2008; Justino 2009; Kalyvas and Kocher 2009). We also ask questions regarding 'connections with influential people' and whether these are used for protective reasons or to gain (in advance) information that might be essential for survival and to exert decisions to migrate. We ask additional questions on whether people try to avoid participation in the community ('distrust'), whether they increase it (through forms of 'information' or 'protest'), and whether they reduce visits to markets to avoid material losses or for protective reasons.

In this part of the module, we have tried to make sure that every action can be directly linked to its driving motivation. A particularly important question is (C4) on the timing of the introduction of these measures, which if successful can allows us to distinguish between ex-ante and ex-post coping strategies.

\footnotetext{
28 "Traditional Remedies" were one of the answer categories in the LSMS Malawi 2004 on the question "What steps have you taken to protect yourself from crime in the past year?".
} 


\section{C6: What type of harm or type of violence is this measure going to protect you from (state the main purpose only)?}

In this case we are interested in the type of violence people want to be protected from. ${ }^{29}$ Answer categories include experiences of discrimination and exclusion ('physical threats/ intimidation/ harassment', 'incursion', 'insults'), actual physical violence such as 'rape' and 'beating/ assault', and those that are more likely to be experienced in a combat ('loss of bodily parts'). ${ }^{30}$ We include further categories that might to be especially expected in unconventional wars such as 'forced labour', 'kidnapping', 'extortion' (Kalyvas 2006; Kalyvas and Kocher 2009). Other categories included are 'robbery' and 'witchcraft'.

Overall, we expect these questions to allow survey users to identify the sources and decisions taken by respondents and their immediate families to prevent future harm and improve safety. The questions should allow also researchers to link different types of measures to perceived threats. These questions, combined with the information collected in the next section on harm experienced by any household member, should allow module users to identify whether protective measures were taken before the actual harm was inflicted (ex-ante coping strategy), or as a response to past experiences (ex-post coping strategies).

\subsection{Section D: Physical Harm and Health}

\section{D1: Which forms of maltreatment do you not consider as violence?}

Injuries have serious implications. "Bullet wounds, shrapnel, and back and chest pain (from beatings and carrying heavy loads)" caused by the LRA have been often reported in Northern Uganda. These have been linked to decreases in the chance of affected people of not being employed in future, may lead to lower wages and may increase deprivation, social dislocation, and vulnerability (Annan, Blattman, and Horton 2006: 44, 47). Capturing the brutality of violent conflicts is a very delicate task in surveys such as the type being proposed. Therefore, before attempting to identify harm inflicted by violence, we think that it is important to identify first context-specific definitions of violence (D1). The International Crime Victim Survey and the European Crime and Safety Survey collect information about sexual offences (i.e. number of offenders, whether offender was known, weapons used). ${ }^{31}$ In their design, they consider that the threshold of what is considered to be 'violence' may be different in different countries. Views might be more similar across people living in urban areas (Van Dijk, Kesteren and Smit 2004/5: 38).

29 Partly adopted from LSMS Malawi 2004.

${ }^{30}$ See WHO (2004: 60) for some guidelines on this question.

${ }^{31}$ Moreover, they incorporate questions on the reasons for owing a gun. 
We incorporated a modified version of the question from the Colombian DHS (1995) to identify what is not considered as violence in the local context.

\section{D2: Have people in your household or have you experienced any of the following? (MULTIPLE ANSWERS) \\ D3: Who was the person experiencing the harm?}

In practice, there exist different approaches to identify the harm that people have experienced. Physical harm is often the first association with violent conflicts. In the LSMS Azerbaijan 1995 and the LSMS Tajikistan 1999, people are asked whether 'any member of your household injured or disabled during the war or when you were leaving your previous home' in the migration section Yet, to define the type of the conflict and understand the harm inflicted, researchers would generally need more concrete information. The health section of the Bosnia and Herzegovina (LSMS 2002-2004) surveys, for example, includes an indirect question of how the person would describe his/her 'disability' - one of the answer options given is 'war wounded'. Respondents are also asked for the time of the occurrence ('In what year did you become disabled?'). Indirectly, the LSMS in Iraq (2006) asks respondents, in the section on 'disabilities and chronic illness', to describe how they became disabled. Among the given answer categories, the respondent can choose 'landmine' and 'war other than landmines'. This questionnaire contains also a section on 'diseases and accidents', where respondents are asked for main causes of injuries. One of the answer categories is 'civil violence'. Another section of the same questionnaire asks whether people did not receive medical care 'for th[eir] illness or injury' due to unsafe situations ('unsafe due to security situation'). More concrete information can be derived if respondents are provided with more answer options. The LSMS Kosovo 2000, for example, includes a question on whether in the last 12 months 'any member of your household been the victim of....?'- 'Corruption/extortion, 'Harassment/threats', 'Physical aggression', 'Theft/robbery', 'Sexual aggression', 'Kidnapping'. Every option is recorded as a dummy (yes/ no recorded for every possible answer). We have drawn on these questionnaires for some of our answer categories on physical harm.

While information on health seems to be relatively well collected, in some instances, some answer categories are still too vague. The meaning of phrases like 'physical' and 'sexual' aggression will differ greatly in different contexts and cultures. Even small differences in the meaning might impede comparisons across countries. To circumvent some of the challenges, it is helpful to train the interviewers better to be sensitive and at the same time try to provide more specific answer codes. The Rwanda Demographic and Health Survey 2005 provides a good example of how this can be done, differentiating carefully, for example, between 'was physically forced to have sexual intercourse' and 'was forced to perform other sexual acts the person did not 
want'. Other categories that can be considered include 'was threatened with knife, gun or other type of weapon', 'was beaten/ assaulted/ kicked', 'was injured by a landmine/ UXO', 'was strangled or burned was forced to labour', 'was kidnapped/ abducted'. These answer categories may provide us with important information on the type of warfare people were exposed to and on the types of strategies followed by the warring groups (see Kalyvas and Kocher 2009).

\section{D4: When was the harm inflicted for the first time? \\ D5: Please specify if the referred person was part of a warring faction when harm was inflicted. (SPECIFY THE WARRING FACTIONS IN CONTEXT) \\ D6: Where did the incident occur? \\ D7: Code for Perpetrator}

We include in the proposed module specific questions that aim to identify whether the person experiencing harm was a combatant or not. We ask directly for whether and which warring faction the person belonged to and indirectly for the location of the incident. Combatants are likely to respond 'on the battlefield/ in a combat operation', while civilians might have been affected 'during transit (e.g. migration)', 'at home', or 'at work (if other than home and not military service)'.

The module contains also questions on perpetrators. Although we recognise that there will be several challenges in phrasing and asking these questions, we have decided to include them in an attempt to establish a better link between violent acts, victims, perpetrators and the consequences of the acts. If successful, this part of the module should help module users to gain a better overall picture of the actual physical vulnerability of certain groups.

As has been outlined in section two, many relevant purposively designed surveys lack these types of questions or concentrate exclusively on one faction only. However, perpetrators are not always those previously assumed (see for example SWAY, Annan, Blattman and Horton 2006). Moreover, the identification of the extent of involvement of certain groups in warfare may be crucial for later peace and reconciliation processes. Obtaining direct links between victims, acts and perpetrators is important to identify different harms in different points of time and locations and link those directly with different perpetrators. This should allow us to capture possible variety and changes of actors that inflict harm (repeatedly).

In this we consider 'household member(s)' and people from the immediate social surrounding (e.g. 'neighbours'). These groups can be set in contrast to 'strangers' and even 'foreigners', which could provide indirect information about the forces involved in the civil war, in particular whether they were local people or from far away. A good example on how to address these delicate issues is provided by the NULS (2007). This survey asks for the 
identity of the perpetrators and respondents are given several answer options including 'Family members'; 'People in the neighbourhood'; 'Local militias'; 'Military'; 'LRA'; 'Other'). We make use of some of these categories in our proposed module.

\section{D8: Has the referred person suffered from any physical or psychological illness of prolonged nature or death, or any afflictions due to the experiences described?}

Usually, surveys measure physical health by asking how far the individual can perform simple tasks. SWAY, for example, defines a serious injury as one that "impedes a youth from doing the physical labour needed for most employment in the region" (Annan, Blattman and Horton 2006: 46). Moreover, as Blattman and Annan's (2007) finding show it is not enough to consider immediate and direct impacts of injuries. Psychological trauma and community rejection would be often experienced by those who suffered from most violence (see also Humphreys and Weinstein (2004; 2007), ICRC (2009)). In setting up our questions in this sections, we are guided by the wording set out by the WHO (2004: 119) and the example provided by the NULS (2007). This question allows us to measure more direct impacts, such as illness of prolonged nature injury handicap psychological distress. Moreover, in the context of inaccessible, overcrowded hospitals, it could be interesting to differentiate whether in case of death the person died immediately or in the hospital, or was even discharged from the hospital.

\subsection{Section E: Displacement}

E1: In (SPECIFY PERIOD OF TIME OF CONFLICT) did you live in the same place as now?

E2: When did you leave your home for the first time?

E3: When did you return to the place you left?

E7: How many times have you changed residence since the beginning of the conflict?

One of the most visible impacts of modern conflicts is the level of population displacement. For instance, in addition to executions, disappearances, kidnapping, and abduction, three to four million have been displaced in Colombia since 1984 (ICRC 2009). The International Displacement Monitoring Center estimates a global total number of 26 million IDPs (December 2008). More than five hundred thousand refugees and asylum seekers from conflict areas were estimated to be living in industrialized countries in 2009 (UNHCR (UNHCR 2010). Although very significant, these numbers tell us little about the challenges that affected people experience before, during and after the movement, including decreases of income and nutrition (Engel and Ibáñez 2007; Fiala 2009; Ibáñez and Moya 2009) and the break-down of families and social protection (Alderman, Hoddinott and Kinsey 2006). 
Few socio-economic household-level questionnaires address the question of why people left their original places of residence. Rather than looking at experiences of (forced) migration, questionnaires typically focus on simply classifying people in different categories ('permanent residence, displaced person, returnee') (see LSMS Bosnia and Herzegovina 2001).

There is also very limited information on refugee's intentions. This problem was faced by the Fafo's research team on Iraqi households in Jordan (Dalen, Stig, Bøås et al. 2009). In their survey they asked whether the refugee intended to stay temporary but missed on those on more permanent residential status. A typical criticism of the type of approach current socio-economic surveys, including the World Bank's LSMS, is summarised in

Kondylis (2007) has criticised this aspect because he was not able to take into account:

"The definition of displacement used in this study does not take into account the individual decision to return to the municipality of origin or to resettle in a new municipality of destination. Indeed, the decision to return or not to the same municipality constitutes an outcome variable in itself. Therefore, consistent estimates of the effect of displacement cannot be obtained on the selected sample of those displaced who returned to the municipality of origin" (2007: 7).

Moreover, Kondylis valuable study on conflict-induced displacement and labour market outcomes in Bosnia-Herzegovina was further constrained due to a lack of information on specific dates:

"[O]nly the date of the last resettlement is recorded. Consequently, the duration of the initial displacement is not observed in the data and I cannot use the period spent in camps as a source of variation in the treatment." (2007: 7).

We address these gaps by including in the module detailed questions on the timing and time span of the displacement. This should provide necessary background information to estimate the impacts of conflict on displacement, as well as of displacement on other socio-economic outcomes. We include also a question on the number of times a person migrated in order to better capture the intensity of this experience.

E4: What was the main reason for you to move to the current location? E8: If you were forced to leave, who forced you to leave your original place of residence? 
Some LSMS surveys have good answer categories on how to identify the causes of migration. The LSMS in Nepal (2003) asks 'What was the main reason for [NAME] to migrate here?' and allows 'political reasons' as a possible answer category. Similarly, 'threat of violence' is one of the answer options in the Tajikistan LSMS 1999. In our module, we include also answer categories that may allow us to capture the driving motivations for ex-ante coping strategies such as 'insurmountable disputes increased in the local area'. The rationale behind this option is to capture the fact that based on escalating problems in its local community, such as land-related tensions or disagreements over water access, the household may have been able to leave the area before the escalation of violence into violent conflict. Other answer categories for household (forced) migration that we have include in the module are: 'security', 'house inhabitable', 'Property destroyed in war', 'war', and 'terrorism. These are included also in LSMS Kosovo 2000, LSMS Timor-Leste 2001, LSMS Bosnia \& Herzegovina 2003 and LSMS Peru 1994.

We include also other categories such as 'famine' and 'disease' in order to better capture the more indirect impacts of violent conflict.

E5: Where did you stay most of the time after leaving home? (SPECIFY PERIOD OF TIME OF CONFLICT)

E6: Please specify the location

We specify the location where people stayed most of the time during the conflict in two ways. First, we tried to identify the social context of the individual by asking whether people relied on networks such as friends or family or rather decided to flee to a refugee camp (E5).

Secondly, we asked for information regarding the geographical location of the relocation site (for instance, whether people migrated to another village or municipality). This information can be specified through municipality and, what is often not considered, country codes. The reasoning behind was to make it possible to analyze whether people could indeed escape from dangerous areas, or whether they - despite small-scale movements - were stuck there. The codes will also allow to more generally inferring on the distances that people left behind, and setting displaced people in the context to their demographic characteristics. To that purpose we are interested in finding out how far can people migrate if they are old, or how far can they move if they had been severely injured before the movement.

\section{E9: Why did you not leave the place despite the outbreak of conflict?}

One innovative aspect of the module proposed is the question of why people did not migrate despite the outbreak of the conflict (E9). This question might reveal information on specific constraints and incentives people experience under extreme situations (e.g. financial constraints or the willingness to 
participate). Justino (2009) differentiates between the extent of the household's vulnerability to poverty and the exposure of the household to violence during conflict or, in other words, its vulnerability to violence to investigate household behaviour in conflict-affected areas. She emphasizes that the inability to move has considerable effects on the vulnerability of the households and their adaptation strategies: " $[\mathrm{H}]$ ouseholds unable to move from areas of conflict [may] resort to armed groups to protect their economic status in times of violence" (2009: 323).

\subsection{Section F: Education}

Violent conflicts results in the reduction of social, economic and political opportunities for certain groups (Justino 2009). This impact is most apparent in the process of human capital formation, which is often interrupted during the conflict. The leading questions for this section are, as Blattman and Miguel argue (2010: 42), not whether wars harm human capital stocks, but rather "in what ways, how much, for whom, and how persistently".

F1: Did you miss school for more than one month in the last years [SPECIFY PERIOD OF TIME IN CONTEXT]?

F2: How long did you stay out of school?

These questions are the first indicators for how persistent the interruption of human capital formation has been. The module asks for the number of months of absence from school. A similar approach had been used in the Timor-Leste LSMS questionnaire (2001), which asks for the duration of absence in the last three months. However, this recall period may be too short if one wants to capture the impacts of long-enduring civil wars. Thus, we ask for the 'number of months' the individual missed school and whether the person ever went back to school after the outbreak of violence.

\section{F3: Why did you miss school or discontinue studies? Please state the main} reason.

The objective of this question is to explore different mechanisms whereby conflict may impact on education. Even in peaceful times reasons for school absence can be manifold and all are important in order to determine the longterm impact of violence on the household, and also on overall economic growth and inequality of the country. This question is also crucial for post-conflict reconstruction, which is probably the reason for its re-occurrence in several LSMS surveys. In the LSMS Bosnia \& Herzegovina 2001 and Kosovo LSMS 2000, for example, reasons for stopping/leaving education school include, amongst others, 'displaced', 'security' and 'harassment'. The Timor-Leste survey (2001) is more detailed allowing respondents to choose between 'family illness/ death' in answering the question of why as a child the household 
member never attended school or stopped attending school. This survey asks also for the reasons of not attending school in different academic years in the past $(1998 / 1999 ; 1999 / 2000 ; 2000 / 2001)$ and for the reasons of planning not to attend the school in the next academic year (2001/2002). In Iraq (2006) a similar question allows respondents to choose 'travel to difficult or unsafe areas' as an answer category. A rather negative approach of identifying reasons for missing or discontinuing school was chosen in Azerbaijan LSMS 1995. One answer option to the question 'Why did (name) miss school or discontinue studies?' is 'Armenian aggression'.

We extended some of the categories discussed above by including the answer category 'school not ready or closed (no teachers/ no building)' indicating the persistence of lack of appropriate infrastructure. During conflicts many children have to leave school and many others do not find the necessary facilities even if they can still attend school. Akbulut-Yuksel (2009) has identified the destruction of schools and the absence of teachers as two important channels explaining the effect of conflict-driven destruction on educational attainment.

There is also evidence that large-scale physical destruction during war has specifically a negatively impact on enrolment of girls (Shemyakina 2006). These channels may also be present in IDP camps. For the case of Northern Uganda, Annan, Blattman and Horton (2006) find that children and classrooms were missing basic materials, such as notebooks and chalk, and even the teachers were often absent.

Comparable questions are sometimes asked in community-level questionnaires such as the Kosovo LSMS, where community leaders can indicate that the 'building [is] not ready', or that there are simply 'no teachers' (Kosovo 2000).

We included in addition other reasons for not attending school such as the inability to pay for fees, transport or uniform, marriage, and the need to search for work. If student's financial support disappears it can lead to widespread patterns of episodic schooling, interrupted by periods where children for example go to work to secure payment for next periods (Annan, Blattman, and Horton 2006). Shemyakina (2006; 2009) suggests that the reasons might lie not only in the unavailability or destruction of schools, but also in a higher reliance on parental support. Instead of asking directly whether school absence was due to 'family illness/ death' as in the Timor-Leste LSMS 2001, we specify whether the child personally ('suffer(ed) from disease or injury'), or the child whether had to take over 'new responsibilities in the household due to illness or death of household members').

In the context of conflict, it is essential to ask whether school absence is due to 'military service'. Annan, Blattman, Mazurana, and Carlson (2009) and Blattman and Annan (2007) argue that the effects of recruitment on income operate via the interruption of schooling, health setbacks and the inability to 
collect relevant working experience. This effect can further be differentiated depending on whether abduction took place. Thus, we also include 'abduction' as an answer category. We expect the inclusion of these nuanced answer categories to allow researchers to better understand the channels whereby violent conflict affects the human capital of individuals and household affected by violence, and enable policymakers to better target interventions to the specific needs of vulnerable groups.

\subsection{Section G: Perceptions of Security}

\section{G1: How save do you feel in your neighbourhood/ local area? G2: Why did you not introduce preventive steps?}

Even long after the official end of war, people might be threatened or feel threatened..$^{32}$ Capturing these perceptions is important as they might explain why some choices over coping strategies are made by individuals and household in areas affected by violent conflict. This section concentrates on overall perceptions of safety. The answer categories were partly adapted from WHO 2004, NULS 2007 and the Afrobarometer. The Afrobarometer, for example, includes such questions on attitudes towards the usage of violence in different contexts (Afrobarometer: Mali 2001, Malawi 2005, Nigeria 2005), as well as the perception of changes in 'safety from crime and violence' (Mali 2001). These types of questions allow us to establish direct links between current political situations and the fear of violence. For instance, the Ghana 2008 asks: "During election campaigns in this country, how much do you personally fear becoming a victim of political intimidation or violence?"). We expect questions G1 and G2 to allow module users to understand better how individuals and households themselves perceive their own security despite the cycle of conflict in which the survey is conducted.

\section{Conclusion}

The main objective of the project was to develop instruments that will help to improve our knowledge of violent conflicts. In particular, we address the need to identify, measure and trace the nature and effects of violent conflict in individual- and household- level surveys in and across conflict-affected areas.

We start by discussing several questionnaire and practices used to date. Our review shows that great improvements in the development of necessary instruments have taken place in the last few years. However, there is still the need to set consistent, comparable and systematic criteria to identify specific conditions whereby violent conflict affects the lives of individuals and households in conflict-affected contexts.

\footnotetext{
32 See Brück and Müller (2010) for a discussion of the determinants of fear over terrorism versus fear over other issues such as crime.
} 
We address this gap in the literature by proposing a module to obtain measurable variables in surveys conducted in conflict-affected areas. We expect this module to allow its users to account for different impacts of violent conflict in different areas, amongst different population groups and across time. The questions will allow researchers to link different types of conflict-related violence with specific types of harm, victims and perpetrator. A specific focus has been set to understand the socio-economic preferences and actual measures introduced by the household members to prevent or limit the impact of the violence. 


\section{Annex I: The Module}

Household Roster

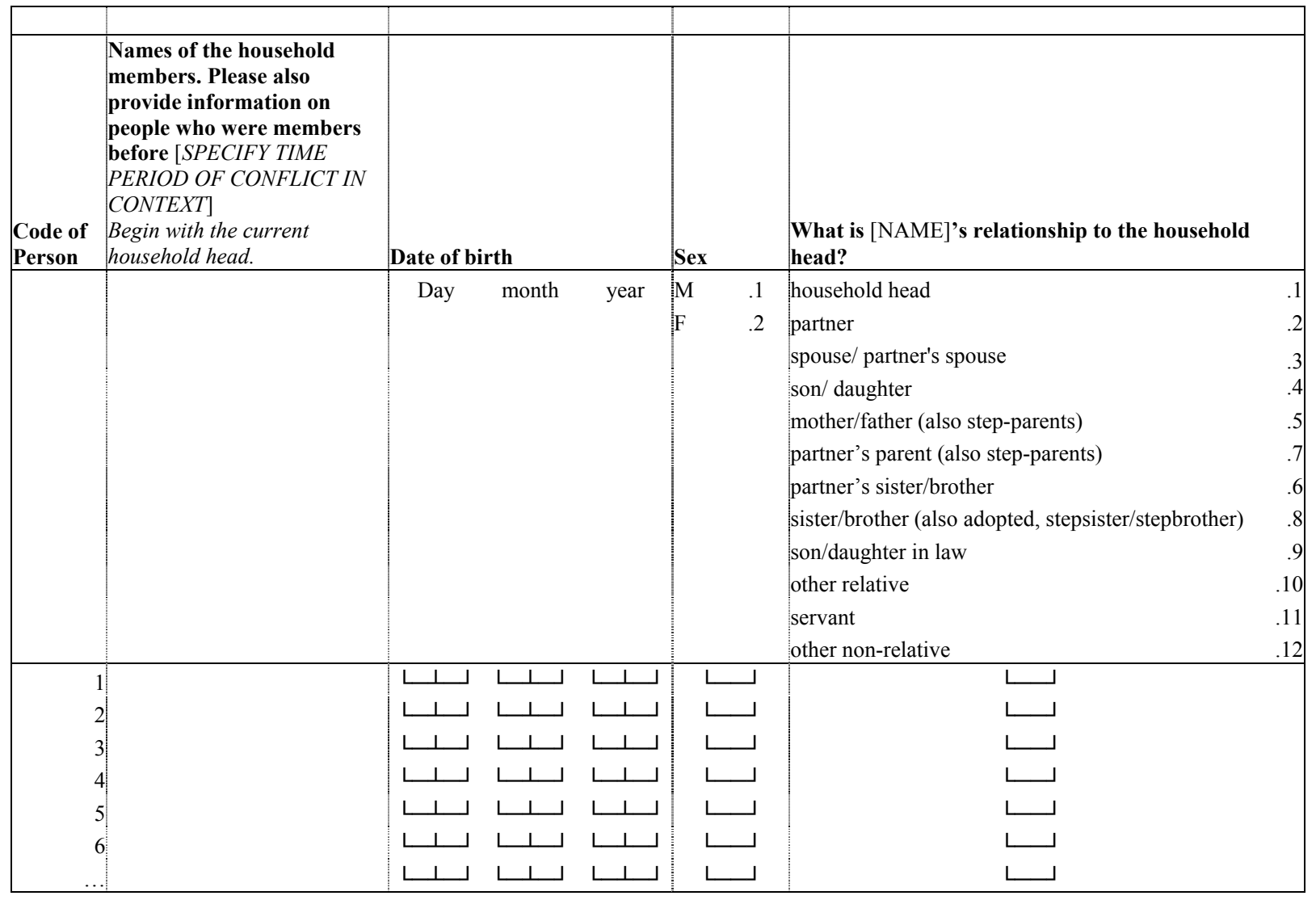


The Module

Section A: Changes in Demographic Characteristics

\begin{tabular}{|c|c|c|c|c|c|}
\hline & $\mathrm{A} 1$ & $\mathrm{~A} 2$ & A3 & A4 & A5 \\
\hline Code of person & Reason why [NAME] has left the household. & $\begin{array}{l}\text { In case }[\mathrm{NAME}] \text { died, what } \\
\text { was the cause of death? }\end{array}$ & $\begin{array}{l}\text { Reason why [NAME] joined the } \\
\text { household. }\end{array}$ & $\begin{array}{l}\text { Date of leaving/ date of death/ date of } \\
\text { joining. }\end{array}$ & $\begin{array}{l}\text { How old was [NAME] } \\
\text { when he } \\
\text { left/died/joined? }\end{array}$ \\
\hline & $\begin{array}{r}\text { divorce/ separation/ widowed } \\
\text { left to get married }\end{array}$ & 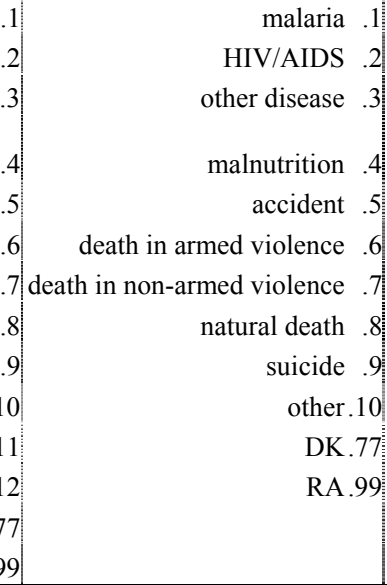 & $\begin{array}{rr}\text { married into household } & .1 \\
\text { divorce/ separation/ widowed } & .2 \\
\text { house inhabitable } & .3 \\
& \\
\text { education } & .4 \\
\text { security/ threats } & .5 \\
\text { more work opportunities } & .6 \\
\text { discrimination } & .7 \\
\text { experienced violence } & .8 \\
\text { other } & .9 \\
\text { DK } & .77 \\
\text { RA } & .99 \\
\end{array}$ & 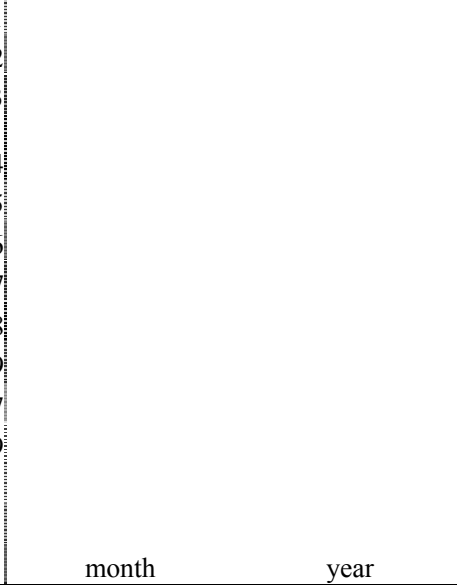 & years \\
\hline$\ldots$ & 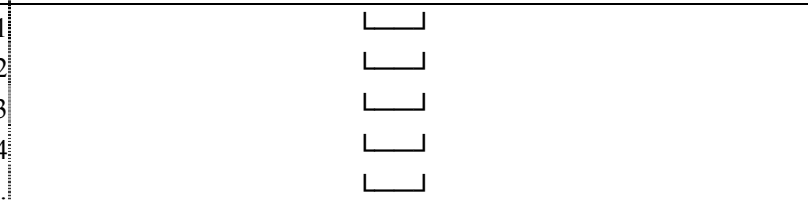 & 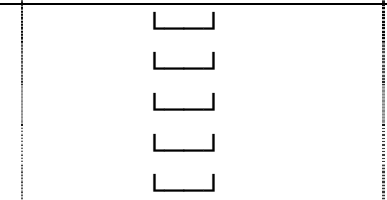 & 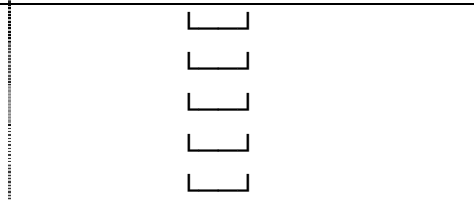 & 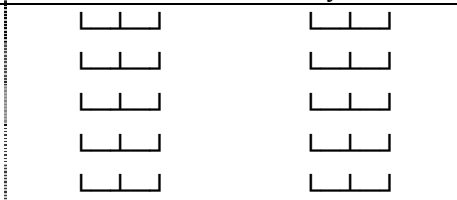 & 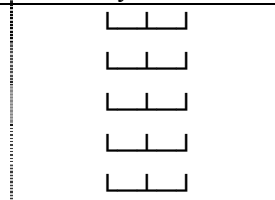 \\
\hline
\end{tabular}


Section B: Economic Welfare

\section{Income}

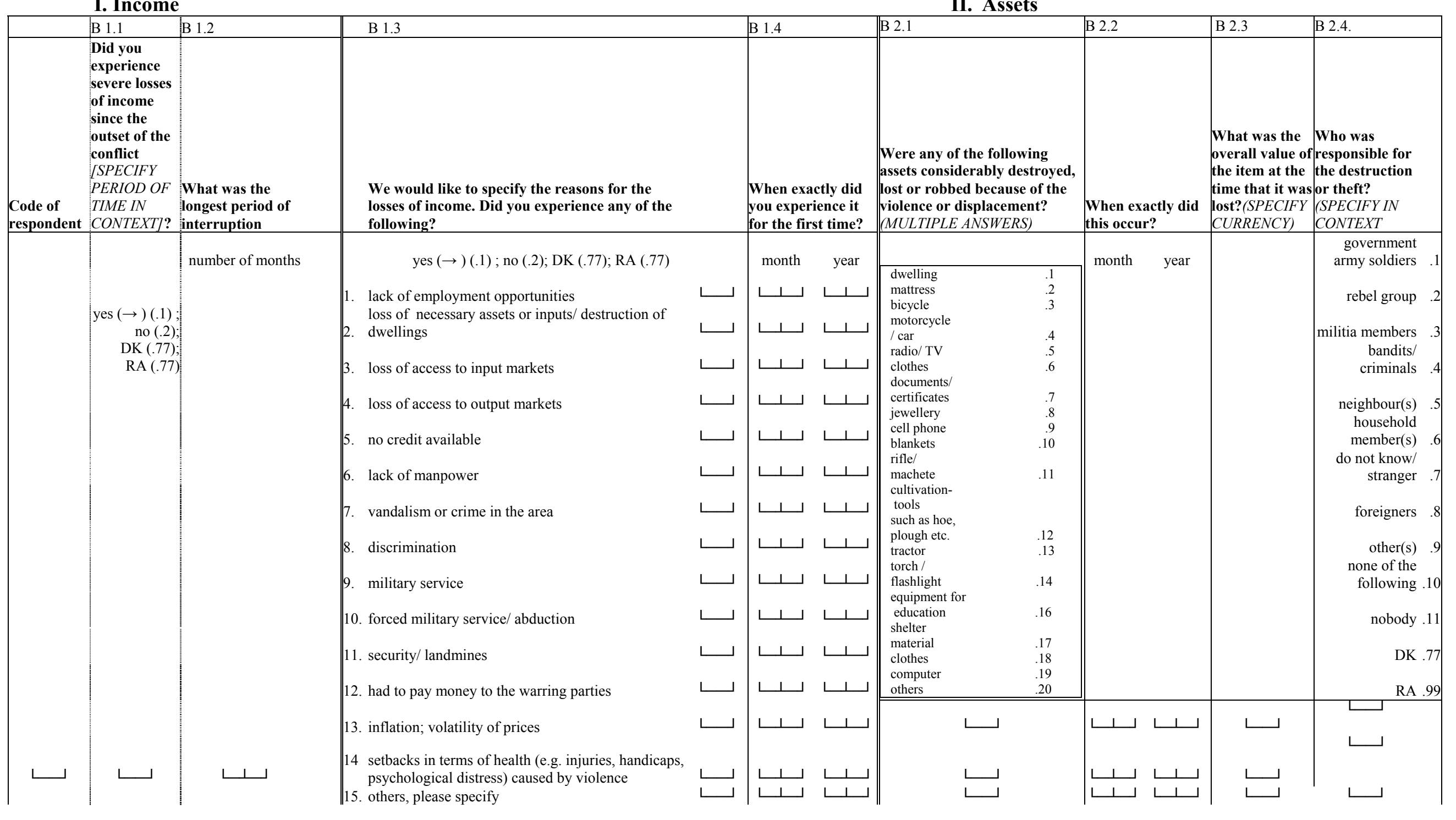




\section{Section C: Activities during Conflict}

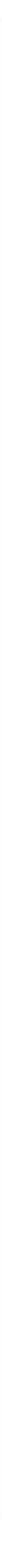


Section D: Harm and Health

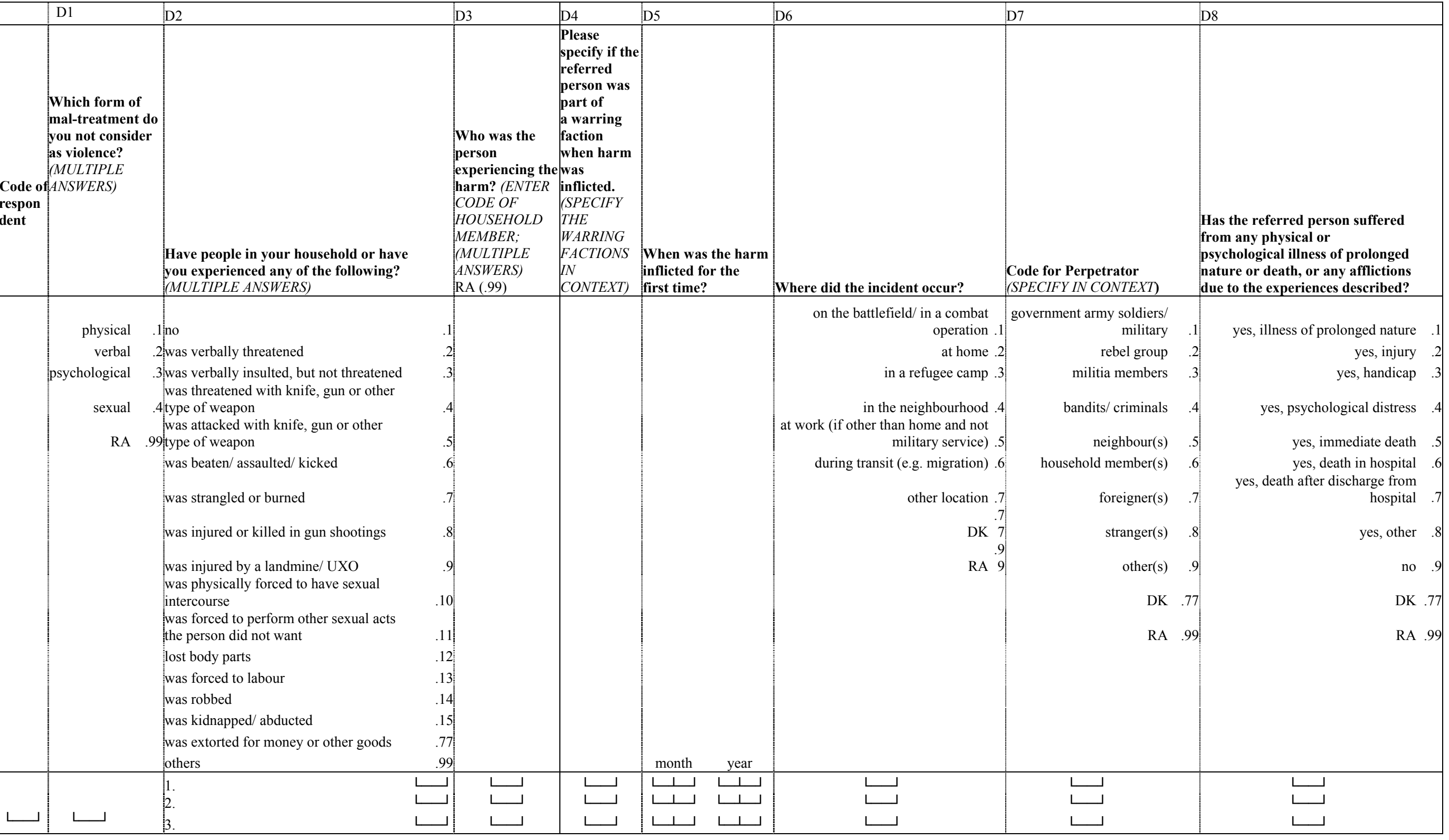


Section E: Displacement

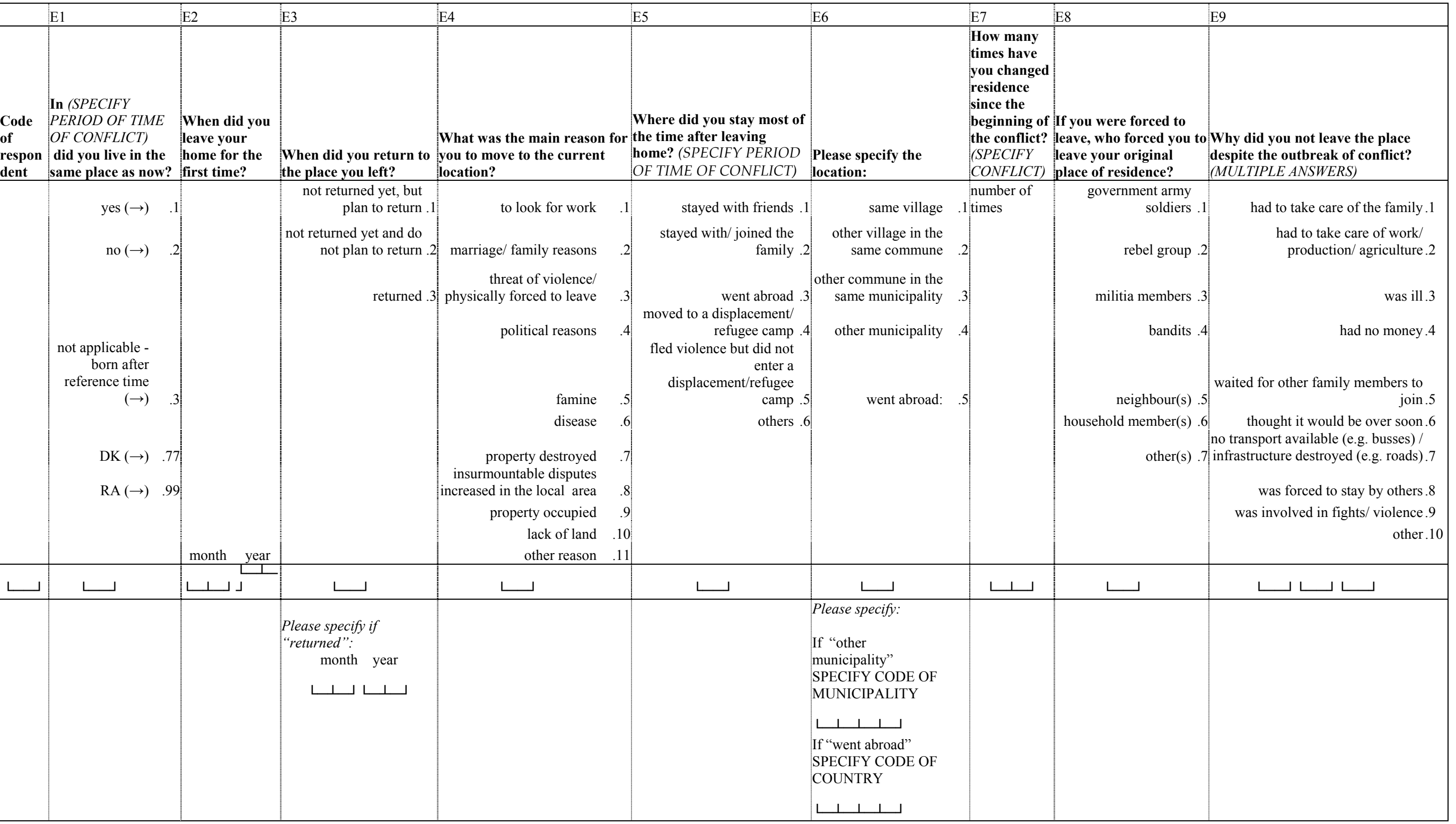


Section F: Education

(SPECIFY AGE OF PARTICIPANTS)

\begin{tabular}{|c|c|c|c|c|c|}
\hline \multirow{3}{*}{$\begin{array}{l}\text { Code of } \\
\text { respondent }\end{array}$} & $\mathrm{F} 1$ & $\mathrm{~F} 2$ & & $\mathrm{~F} 3$ & \multirow{4}{*}{$\begin{array}{l}\text { CODE FOR QUESTION : } \\
\text { displaced, no school available (.1), travelling too difficult or too far }(.2) \text {, it was not safe to go to school } \\
\text { (.3), new responsibilities in the household due to illness or death of household members }(.4) \text {, got married } \\
\text { (.5), suffer(ed) from disease or injury (.6), had a good working opportunity }(.7) \text {, was searching for a } \\
\text { working opportunity (.8), harassment/ injustice at school (e.g. ethnic based or religious exclusion) }(.9) \text {, } \\
\text { unable to pay for fees/transport/ uniform (.10), military service (.11), school not ready or closed (no } \\
\text { teachers/ no building) (.12), abduction (.13), hunger (.14), anticipation of punishment (.15), other } \\
\text { reason (.16), DK (.77), RA (.99) }\end{array}$} \\
\hline & $\begin{array}{l}\text { Did you miss school for } \\
\text { more than one month in the } \\
\text { last years (SPECIFY } \\
\text { PERIOD OF TIME IN } \\
\text { CONTEXT)? }\end{array}$ & \multicolumn{2}{|c|}{$\begin{array}{l}\text { How long did you stay out of school? } \\
\text { Do not count holidays. }\end{array}$} & $\begin{array}{l}\text { Why did you miss school or } \\
\text { discontinue studies? Please } \\
\text { state the main reason. }\end{array}$ & \\
\hline & $\begin{array}{r}\text { Yes (.1), no (.2), DK } \\
(.77), \text { RA (.99) } \\
\end{array}$ & number of months & $\begin{array}{l}\text { never went to } \\
\text { school again }\end{array}$ & & \\
\hline لـــــ & ــ & لـــــ & ـــ & ــ & \\
\hline
\end{tabular}

\section{Section G: Perceptions of Security}

\begin{tabular}{|c|c|c|c|c|}
\hline & & \multicolumn{2}{|l|}{$\mathrm{G} 1$} & G2 \\
\hline \multicolumn{2}{|l|}{\begin{tabular}{|l|}
$\begin{array}{l}\text { Code of } \\
\text { respondent }\end{array}$ \\
\end{tabular}} & \multicolumn{2}{|l|}{ How safe do you feel in your neighbourhood/ local area? } & Why did you not introduce preventive steps? \\
\hline & & & & no need, feel safe .1 \\
\hline & & & & no need, do not care .2 \\
\hline & & & & because nothing can be done .3 \\
\hline & & & & because given enough time things will be resolved by themselves .4 \\
\hline & & & & no money .5 \\
\hline \multirow{11}{*}{ 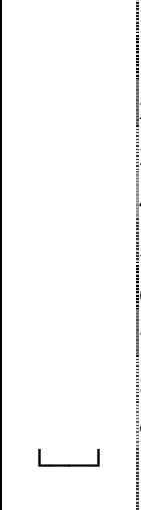 } & & strongly agree (.1); agree (.2); disagree (.3); strongly disagree (.4); RA (.99 & & others .6 \\
\hline & 1. & I feel safe when walking alone in the neighbourhood during the day. & $\longleftarrow$ & \\
\hline & 2. & I feel safe when walking alone in the neighbourhood during the night. & 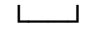 & \\
\hline & 3. & I feel safe from crime and violence when I am alone at home. & $\longleftarrow$ & \\
\hline & 4. & I avoid using certain ways and do not go to certain areas that I think are dangerous. & 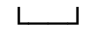 & \\
\hline & 5. & My neighbourhood is peaceful overall. & 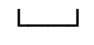 & \\
\hline & 6. & My neighbourhood is marked by the repeated occurrence of violence. & $\longleftarrow$ & \\
\hline & 7. & The level of violence has increased a lot compared to two years ago. & 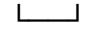 & \\
\hline & 8. & It is very likely that in the next 12 months I will become a victim of violence. & 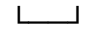 & \\
\hline & 9. & I never hear weapons being fired in my neighbourhood. & $\longleftarrow$ & \\
\hline & 10 & The police is doing a good job. & \llcorner & 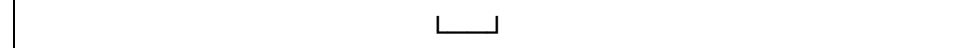 \\
\hline
\end{tabular}




\section{Annex II: Surveys with Conflict-Related Questions by Regions}

\begin{tabular}{l|l} 
Azerbaijan & $\begin{array}{l}\text { World Bank, 1995: The Living Standards Measurement Study (LSMS) Azerbaijan, } \\
\text { Household Survey. }\end{array}$ \\
\hline Bosnia \& & World Bank, 2001-2004: LSMS Bosnia \& Herzegovina, Household Survey. \\
\hline Burundi & $\begin{array}{l}\text { Burundi Institute of Statistics, 1999: The Burundi Priority Survey, October 1998 } \\
\text { and March 1999. }\end{array}$ \\
\cline { 2 - 3 } $\begin{array}{l}\text { Samii, Cyrus/ Eric Mvukiyehe/ Gwendolyn Taylor, 2007: 2007 National Survey } \\
\text { Instruments, Burundi. Civilian Questionnaire - English Translation, } \\
\text { http://www.columbia.edu/ cds81/burundisurvey/ (07/04/2010). }\end{array}$ & $\begin{array}{l}\text { Bundervoet, Tom/ Eleonora Nillesen/ Philip Verwimp/ Maarten Voors, 2009: } \\
\text { Integrating Conflict Questions in a Household Survey: An Example from } \\
\text { Burundi. HiCN Research Design Note 12. }\end{array}$ \\
\hline Colombia & $\begin{array}{l}\text { PROFAMILIA, Asociación Pro-Bienestar de la Familia Colombiana and Macro } \\
\text { International, 1995: Demographic and Health Survey (DHS) Colombia. } \\
\text { Arjona, Ana M./ Stathis N. Kalyvas, 2008: Rebelling Against Rebellion: } \\
\text { Comparing Insurgent and Counter-insurgent Recruitment, } \\
\text { http://www.crise.ox.ac.uk/copy/mobilisation\%20conference/arjona_kalyvas.pd } \\
\text { f(07/04/2010). }\end{array}$ \\
\hline Cote d'Ivoire & $\begin{array}{l}\text { Mvukiyehe, Eric/ Cyrus Samii, 2008: Laying a Foundation for Peace? A } \\
\text { Quantitative Impact Evaluation of the United Nations Operation in Cote d'Ivoire, } \\
\text { http://www.columbia.edu/ cds81/docs/unoci/ics2008_report081218.pdf } \\
\text { (07/04/2010). }\end{array}$ \\
\hline Darfur Refugee Questionnaire (DRQ). In: Samuel Totten/ Eric Markusen (eds.), \\
2006: Genocide in Darfur: investigating the atrocities in the Sudan. Taylor \& \\
Francis Group, LLC.
\end{tabular}


Fafo-Ais, Iraqis in Jordan 2007, survey:

http://www.fafo.no/ais/middeast/jordan/IJ_QENG.pdf , report:

http://www.fafo.no/ais/middeast/jordan/IJ.pdf (07/04/2010).

\begin{tabular}{l|l}
\hline Kosovo & $\begin{array}{l}\text { World Bank, 2000: LSMS Kosovo, Household Survey - Individual Survey - } \\
\text { Community Survey. }\end{array}$ \\
\hline \multirow{2}{*}{ Liberia } & $\begin{array}{l}\text { Taylor, Gwendolyn, 2007: CHF International 2007. Ex-combatant Economic } \\
\text { Reintegration Survey (Lofa County). }\end{array}$ \\
\cline { 2 - 2 } & Pugel, James, 2006: UNDP Liberia Ex-Combatant Survey Nr. 1. Field Guide for \\
& Enumerators and Supervisors. February-March 2006, \\
& http:// www.columbia.edu/ mh2245/XCSURVEYS/LIBERIA_FEB06_METHOD \\
& $\begin{array}{l}\text { pdf; survey accessible at: } \\
\text { http:// www.columbia.edu/ mh2245/XCSURVEYS/LIBERIA_FEB06.pdf } \\
(23 / 04 / 2010) .\end{array}$
\end{tabular}

(Results published in: Pugel, James. 2006: What the Fighters Say: A Survey of Excombatants in Liberia. UNDP Liberia.)

Eric Mvukiyehe/ Cyrus Samii, 2008: Laying a Foundation for Peace in Liberia. December 23, 2008

Fearon, James D. / Macartan Humphreys/ Jeremy M. Weinstein, 2009: Can Development Aid Contribute to Social Cohesion after Civil War? Evidence from a Field Experiment in Post-Conflict Liberia. American Economic Review: Papers \& Proceedings, 99 (2) 287-291. Data and Codebook available at Macartan Humphreys' personal website.

\begin{tabular}{|c|c|}
\hline \multirow[t]{2}{*}{ Malawi } & World Bank, 2004: LSMS Malawi, Community Survey - Household Survey. \\
\hline & AfroBarometer 2005, Attitudes to Democracy and Market in Malawi. \\
\hline Mali & AfroBarometer 2001, Attitudes to Democracy and Market in Mali. \\
\hline \multirow[t]{2}{*}{ Nepal } & World Bank, 1996, 2003: LSMS Nepal, Household Survey. \\
\hline & $\begin{array}{l}\text { Samii, Cyrus/ Michael Gilligan/ Kristine Eck, 2009: Nepal Peacebuilding Survey: } \\
\text { Study Design, December 10, } 2009\end{array}$ \\
\hline Nigeria & $\begin{array}{l}\text { Guichaoua, Yvan, 2007: Who joins ethnic militias? A survey of the Oodua } \\
\text { People's Congress in South-western Nigeria. Crise Working Paper, 44, March } \\
2007 \text {. }\end{array}$ \\
\hline Peru & World Bank, 1991, 1994: LSMS Peru, Household Survey. \\
\hline $\begin{array}{l}\text { Republic of } \\
\text { Mozambique }\end{array}$ & $\begin{array}{l}\text { Republic of Mozambique, Ministry of Agriculture, 2005: National Agricultural } \\
\text { Survey 2005, Small- and Medium-Sized Farms-Panel, } \\
\text { http:// www.aec.msu.edu/fs2/mozambique/survey/index.htm (07/04/2010). } \\
\text { Not directly related to conflict this survey has a good section on 'coping } \\
\text { strategies'. }\end{array}$ \\
\hline Rwanda & $\begin{array}{l}\text { Rwandan Rural Labour and Death Survey, 2002, } \\
\text { http://www.aec.msu.edu/fs2/Rwanda/deathhistory_eng.pdf (07/04/2010). }\end{array}$ \\
\hline
\end{tabular}
Institut National de la Statistique Ministère des Finances et de la Planification Économique Kigali, Rwanda, 2006: Rwanda Demographic and Health Survey 2005. Calverton: ORC Macro. 


\begin{tabular}{|c|c|}
\hline & Scott Straus. Rwanda Prisoner Questionnaire 2002 Questionnaire \\
\hline & $\begin{array}{l}\text { Christian Davenport and Allan Stam Butare Survey, } \\
\text { http:/ / www.columbia.edu/ mh2245/XCSURVEYS/BUTARE.pdf (07/04/2010). }\end{array}$ \\
\hline Serbia & World Bank, 2002: LSMS Serbia, Household Survey - Individual Survey. \\
\hline \multirow[t]{2}{*}{ Sierra Leone } & $\begin{array}{l}\text { Humphreys, Macartan/ Jeremy Weinstein/ PRIDE-Salone, 2003: Sierra Leone Ex- } \\
\text { Combatant Survey \#1, survey available at: } \\
\text { http:/ / www.columbia.edu/ } \sim \text { mh2245/Survey.pdf }(28 / 04 / 2010) .\end{array}$ \\
\hline & $\begin{array}{l}\text { PRIDE/ International Center for Transitional Justice, 2002: Ex-Combatant Views } \\
\text { of the Truth and Reconciliation Commission and the Special Court in Sierra } \\
\text { Leone, http://www.ictj.org/images/content/0/9/090.pdf (survey and report) } \\
(28 / 04 / 2010) .\end{array}$ \\
\hline Tajikistan & World Bank, 1999: LSMS Tajikistan, Household Survey - Population Point. \\
\hline Timor-Leste & World Bank, 2001: LSMS Timor-Leste, Household Survey - Individual Survey. \\
\hline \multirow[t]{4}{*}{ Uganda } & $\begin{array}{l}\text { Blattman, Chris, 2005: Uganda: Survey of War-affected Youth (SWAY), } \\
\text { Household-Survey, http:// chrisblattman.com/data/sway/ }\end{array}$ \\
\hline & $\begin{array}{l}\text { Blattman, Chris, 2005/6: Uganda: Survey of War-affected Youth (SWAY), Phase } 1 \\
\text { (Males) Individual survey, http://chrisblattman.com/data/sway/. }\end{array}$ \\
\hline & $\begin{array}{l}\text { Blattman, Chris, 2007: Uganda: Survey of War-affected Youth (SWAY), Phase } 2 \\
\text { (Females) Individual survey, http://chrisblattman.com/data/sway/. }\end{array}$ \\
\hline & $\begin{array}{l}\text { Fafo AIS, 2007: Northern Uganda Livelihood Survey. } \\
2005 \text { Northern Uganda Internally Displaced Persons Profiling Study } \\
2006 \text { Lira District Early Recovery Needs Assessments. }\end{array}$ \\
\hline Vietnam & $\begin{array}{l}\text { Kalyvas, Stathis N./ Matthew Adam Kocher, 2009: The Dynamics of Violence in } \\
\text { Vietnam: An Analysis of the Hamlet Evaluation System (HES). Journal of Peace } \\
\text { Research, 46: 335-355. Survey available under } \\
\text { www.prio.no/misc/Download.aspx?file...Data\%2FKK_appendix.doc } \\
(27 / 04 / 2010) .\end{array}$ \\
\hline
\end{tabular}

Demographic and Health Survey (DHS),

http://www.measuredhs.com/aboutsurveys/dhs/start.cfm (20/04/2010). 


\section{Project Team}

Alexandra Avdeenko is PhD student at the DIW Berlin Graduate Center. She obtained her Bachelors in Political Science and Economics with distinction from the University of Mannheim, Germany. Her academic study was continued and completed with distinction at the University of Warwick, Master in International Political Economy. She has working experience at the Peace Research Institute Frankfurt, the German Council on Foreign Relations and the German Institute for Economic Research. Her major interests lie in international development, with a focus on transition and conflict-affected countries.

Tilman Brück is Head of the Department of International Economics at the German Institute for Economic Research (DIW Berlin) and Professor of Development Economics at Humboldt-University of Berlin. He studied economics at Glasgow University and Oxford University and obtained his doctorate in economics from Oxford University. His research interests include the economics of household behaviour and well-being in conflict and post-conflict economies and the economics of terrorism and insecurity. He has worked on many developing including Mozambique, Nicaragua, Syria, Tanzania, Uganda and Ukraine. Professor Brück is a co-founder and co-director of the "Households in Conflict Network" (http://www.hicn.org).

Patricia Justino is Fellow at the Institute of Development Studies in the Vulnerability and Poverty Reduction team. Patricia is co-director and co-founder of the Households in Conflict Network (with Tilman Brück and Philip Verwimp), and director of MICROCON, a large research programme on the micro-level analysis of violent conflict funded by the European Commission. Her current research work focuses on the microeconomic analysis of the impact of violent socio-political conflict on household welfare. Other research work includes the measurement of non-monetary dimensions of inequality and their effects on social development and economic growth, the measurement and modelling of poverty (static and dynamic), the role of social security and redistribution on economic growth, political instability and household welfare in developing countries and the impact of economic shocks on household income mobility in developing countries.

Philip Verwimp is Associate Professor and holder of the Alain and Marie Philippson Chair in Sustainable Human Development at the Solvay Brussels School of Economics and Management, Universite Libre de Bruxelles. He obtained his $\mathrm{PhD}$ in Economics from the Catholic University of Leuven in January 2003 with a dissertation on the political economy of development and genocide in Rwanda. He specializes in the economic causes and consequences of conflict at the micro-level. Philip has done quantitative work on the death toll of the genocide and on the demography of postgenocide Rwanda. He currently works on poverty and health in conflict-affected countries. Philip was a Fulbright-Hays Fellow at Yale University and worked for the World Bank as a Poverty Economist. He received the Jacques Rozenberg Award from the Auschwitz Foundation for his dissertation. 


\section{References}

Akbulut-Yuksel, Mevlude (2009). "Children of war the long-run effects of large-scale physical destruction and warfare on children." HiCN Working Paper 62.

Akresh, Richard, Philip Verwimp and Tom Bundervoet ( forthcoming 2011). "Crop failure, civil war and child stunting in Rwanda." Economic Development and Cultural Change.

Akresh, Richard and Damien de Walque (2008). "Armed conflict and schooling: Evidence from the 1994 Rwandan genocide " HiCN Working Papers 47.

Alderman, Harold, John Hoddinott and Bill Kinsey (2006). "Long term consequences of early childhood malnutrition." Oxford Economic Papers 58(3): 450-474.

Alva, Soumya, Edmundo Murrugarra and Pierella Paci (2002). "The hidden costs of ethnic conflict decomposing trends in educational outcomes of young Kosovars." World Bank Policy Research Working Paper 2880.

Annan, Jeannie, Christopher Blattman and Roger Horton (2006). "The state of youth and youth protection in northern Uganda findings from the survey for war affected youth. A report for UNICEF Uganda. September 2006."

Annan, Jeannie, Christopher Blattman, Dyan Mazurana and Khristopher Carlson (2009). Wives mothers and fighters in the lord's resistance army New Haven, Mimeo.

Arjona, Ana M. and Stathis N. Kalyvas (2008). "Rebelling against rebellion comparing insurgent and counter-insurgent recruitment."

Bardhan, Pranab, Jean-Marie Baland, Sanghamitra Das, Dilip Mookherjee and Rinki Sarkar (2002). "The environmental impact of poverty: Evidence from firewood collection in rural Nepal. Dp-126. The institute for economic development. Boston university."

Beber, Bernd and Christopher Blattmann (2010). "The industrial organization of rebellion: The logic of forced recruitment and child soldiering." HiCN Working Paper 72.

Beegle, Kathleen, Joachim De Weerdt and Stefan Dercon (2008). "Migration and economic mobility in Tanzania: Evidence from a tracking survey." The World Bank, Policy Research Working Paper Series 4798.

Bhaumik, Sumon, Ira Gang and Myeong-Su Yun (2005). "Ethnic conflict and economic disparity: Serbians \& Albanians in Kosovo." William Davidson Institute Working Paper 808.

Bhaumik, Sumon, Ira Gang and Myeong-Su Yun (2008). "Gender and ethnicity in post-conflict Kosovo." United Nations University, UNU-Wider Research Paper 43.

Bjørkhaug, Ingunn, Morten Bøås, Anne Hatløy and Kathleen M. Jennings. (2008). "Returning to uncertainty? Addressing vulnerabilities in northern Uganda." Retrieved 28/04/2010, from http://www.fafo.no/nyhet/return2uncertanity.pdf

Blattman, Christopher (2009). "From violence to voting: War and political participation in Uganda." The American Political Science Review 103(2): 231-247. 
Blattman, Christopher and Jeannie Annan (2007). "The consequences of child soldiering." HiCN Working Paper 22.

Blattman, Christopher and Edward Miguel (2010). "Civil war." \ournal of Economic Literature 48(1): 3-57.

Bohara, Alok K., Neil J. Mitchell and Mani Nepal (2006). "Opportunity, democracy, and the exchange of political violence." Journal of Conflict Resolution, pp. 108-128 vol. 50:.

Bozzoli, Carlos and Tilman Brück (2009a). „Agriculture, Poverty and Post-War Reconstruction: MicroLevel Evidence from Northern Mozambique“. Journal of Peace Research, vol. 46, no. 3, pp. 377-97.

Bozzoli, Carlos and Tilman Brück (2009b). „Identifying Conflict and its Effects Using Micro-Level Surveys". HiCN Research Design Notes, Nr. 13.

Brück, Tilman (2004). "Coping strategies in post-war rural Mozambique." HiCN Working Paper 2.

Brück, Tilman and Kati Schindler (2009a). "Smallholder Land Access in Post-War Northern Mozambique“. World Development, vol. 37, no. 8, pp. 1379-89.

Brück, Tilman and Kati Schindler (2009b). "The impact of violent conflicts on households: What do we know and what should we know about war widows?" Oxford Development Studies 37(3): 289 - 309.

Brück, Tilman and Cathérine Müller (2010). „Comparing the Determinants of Concern about Terrorism and Crime“. Global Crime, vol. 11, no 1, pp. 1-15.

Bundervoet, Tom (2006). "Estimating poverty in Burundi." Households in Conflict Network Working Paper 20.

Bundervoet, Tom, Eleonora Nillesen, Philip Verwimp and Maarten Voors (2009). "Integrating conflict questions in a household survey: An example from Burundi." HiCN Research Design Note 12.

Bundervoet, Tom (2009). "Livestock, Land and Political Power: The 1993 killings in Burundi" Journal of Peace Research 46: 357-376.

Bundervoet, Tom, Philip Verwimp and Richard Akresh (2009). "Health and civil war in rural Burundi." Journal of Human Resources 44(2): 536-563.

Burnham, Gilbert M. (2008). "Violence-related mortality in Iraq, 2002-2006." The New England Journal of Medicine 359(4): 431- 434.

Burnham, Gilbert M., Riyadh Lafta, Shannon Doocy and Les Roberts (2006). "Mortality after the 2003 invasion of Iraq: A cross-sectional cluster sample survey." The Lancet 368: 1421-1428.

Calderón, Valentina and Ana María Ibáñez (2009). "Labor market effects of migration-related supply shocks: Evidence from internally displaced populations in Colombia." MICROCON Research Working Papers 14.

Collier, Paul and Anke Hoeffler (1998). "On economic causes of civil war." Oxford Economic Papers 50(4): 563-573. 
Cramer, Christopher (2006). Civil war is not a stupid thing: Accounting for violence in developing countries. London, Hurst \& Company.

Czaika, Mathias and Krisztina Kis-Katos (2009). "Civil conflict and displacement - village-level determinants of forced migration in Aceh." \ournal of Peace Research 46(3): 399-418.

Dalen, Kristin, Karianne Stig, Morten Bøås, Jon Pedersen and Anne Hatløy (2009). The development of a conflict module in survey research. Oslo, Norway, Fafo.

Davenport, Christian and Allan C. Stam. (2009). "What really happened in Rwanda?" Retrieved 07/04/2010, from http://rwandarwabanyarwanda.over-blog.com/article-christian-davenport-and-allanc-stam-what-really-happened-in-rwanda-45022893.html

De Walque, Damien (2004). "The long-term legacy of the Khmer Rogue period in Cambodia." World Bank Research Paper 3446.

De Walque, Damien and Philip Verwimp (2010). "The demographic and socio-economic distribution of excess mortality during the 1994 genocide in Rwanda." Journal of African Economies 19(2): 141-162.

Deaton, Angus (2000). The analysis of household surveys: A microeconometric approach to development policy. Baltimore, Maryland, The World Bank, John Hopkins University Press.

Deaton, Angus (2001). "Counting the world's poor: Problems and possible solutions." World Bank Research Observer 16(2).

Degomme, Olivier and Debarati Guha-Sapir (2007). "Mortality and nutrition surveys by non-governmental organizations. Perspectives from the Ce-Dat database." Emerging Themes in Epidemiology 4(11): 1-5.

Deininger, Klaus, Ana María Ibáñez and Pablo Querubin (2004). "Towards sustainable return policies for the displaced population: Why are some displaced households more willing to return than others?" $\mathrm{HiCN}$ Working Paper 07.

Do, Quy-Toan and Lakshmi Iyer (2009). "Mental health in the aftermath of conflict." Harvard Business School Working Paper 10-040

El-Bushra, Judy (2003). Women building peace: Sharing know-how. London, International Alert.

Elbadawi, Ibrahim and Nicholas Sambanis (2002). "How much war will we see? Explaining the prevalence of civil war." Journal of Conflict Resolution 46(3): 307-334.

Engel, Stefanie and Ana Maria Ibáñez (2007). "Displacement due to violence in Colombia: A householdlevel analysis." Economic Development and Cultural Change 55(2): 335-365.

ERD, European Report on Development (2009). "Overcoming fragility in Africa: Forging a new European approach."

Fearon, James D. (2004). "Why do some civil wars last so much longer than others?" Journal of Peace Research, pp. 275-301 vol. 41:

Fearon, James D., Macartan Humphreys and Jeremy M. Weinstein (2009). "Can development aid contribute to social cohesion after civil war? Evidence from a field experiment in post-conflict Liberia." American Economic Review: Papers \& Proceedings 99(2): 287-291. 
Fearon, James and David Laitin (2003). "Ethnicity, insurgency and civil war." American Political Science Review 97(1): 75-90.

Fiala, Nathan (2009). "The consequences of forced displacement in northern Uganda." HiCN Working Paper 65(October).

Food and Agriculture Organization, FAO. (1996). "Study on the impact of armed conflicts on the nutritional situation of children." Retrieved 26/04/2010, from http://www.fao.org/docrep/005/w2357e/W2357E05.htm.

Gates, Scott (2002). "Recruitment and allegiance: The microfoundations of rebellion." Journal of Conflict Resolution 46(1): 111-130.

Ghobarah, Hazem, Paul Huth and Bruce Russett (2003). "Civil wars kill and maim people long after the shooting stops." American Political Science Review 97(2): 189-202.

Goodwin, Jeff (2001). No way out: States and revolutionary movements 1945-1991. Cambridge, Cambridge University Press.

Green, Eric P. and Ocaka Oscar Tony (2008). "Village leaders as data collectors: Willing, capable, and rational." HiCN Research Design Note 9.

Grossman, Herschel I. (1991). "A general equilibrium model of insurrections." American Economic Review: Papers \& Proceedings 81: 912 - 921.

Guerrero-Serdán, Gabriela (2009). "The effects of the war in Iraq on nutrition and health: An analysis using anthropometric outcomes of children." HiCN Working Paper 55.

Guichaoua, Yvan (2007). "Who joins ethnic militias? A survey of the Oodua people's congress in southwestern Nigeria." Crise Working Paper 44(March).

Gupta, Dipak K. (1990). The economics of political violence: The effect of political instability on economic growth. New York, Praeger.

Hatlebakk, Magnus (2007). "LSMS data quality in Maoist influenced areas of Nepal." CMI WP 6.

Hegre, Håvard. (2002). "Some social requisites of a democratic civil peace: Democracy, development, and armed conflict." Retrieved 24/04/2010, from http:/ / citeseerx.ist.psu.edu/viewdoc/download?doi=10.1.1.19.5933\&rep=rep1\&type=pdf

Humphreys, Macartan (2008). "Community driven reconstruction in the democratic republic of Congo baseline report. May 2008."

Humphreys, Macartan and Jeremy M. Weinstein (2007). "Demobilization and reintegration." Journal of Conflict Resolution 51(4): 531-567.

Humphreys, Macartan and Jeremy M. Weinstein. (2004). "What the fighters say. A survey of excombatants in Sierra Leone June-August 2003." Retrieved 07/04/2010, from http://www.columbia.edu/ mh2245/Report1_BW.pdf 
Humphreys, Macartan and Jeremy M. Weinstein (2008). "Who fights? The determinants of participation in civil war." American Journal of Political Science 52(2): 436-455.

Ibáñez, Ana María and Andés Moya (2009). "Do conflicts create poverty traps? Asset losses and recovery for displaced households in Colombia." MICROCON Research Working Papers 10.

Ibáñez, Ana María and Andrea Velásquez (2009). "Identifying victims of civil conflicts: An evaluation of forced displaced households." Colombia Journal of Peace Research 46: 431- 451.

Ilahi, Nadeem (2001). "Children's work and schooling: Does gender matter? Evidence from the Peru LSMS panel data." Policy Research Working Paper 2745.

International Committee of the Red Cross (1999). "The people on war report ICRC worldwide consultation on the rules of war."

International Committee of the Red Cross (2009). "Summary report: Afghanistan, Colombia, democratic republic of Congo, Georgia, Haiti, Lebanon, Liberia and the Philippines. Opinion survey and in-depth research."

Jacoby, Hannan G. (2000). "Access to markets and the benefits of rural roads." Economic Journal 110(465): 713-737.

Justino, Patricia. (2008). "The impact of armed civil conflict on household welfare and policy responses." Retrieved 10/04/2010, from http://www.un.org/esa/policy/wess/wess2008files/ws08backgroundpapers/justino_2008.pdf.

Justino, Patricia (2009). "Poverty and violent conflict: A micro-level perspective on the causes and duration of warfare." Journal of Peace Research 46 (3): 315-333.

Justino, Patricia (forthcoming 2010). War and poverty: Handbook of the economics of peace and security, Oxford University Press.

Justino, Patricia and Olga N. Shemyakina (2008). "Private and public transfers as a coping strategy under armed conflict: The case of Tajikistan." Working Paper.

Kalyvas, Stathis N. (2006). The logic of violence in civil war. Cambridge, Cambridge University Press.

Kalyvas, Stathis N. and Matthew Adam Kocher (2007). "How free is "Free-riding" In civil wars? Violence, insurgency, and the collective action problem." World Politics 59(2): 177-216.

Kalyvas, Stathis N. and Matthew Adam Kocher (2009). "The dynamics of violence in Vietnam: An analysis of the hamlet evaluation system (HES)." Journal of Peace Research 46: 335-355.

Keen, David (1998). The economic functions of violence in civil wars, Routledge.

Kondylis, Florence (2007). "Conflict-induced displacement and labour market outcomes: Evidence from post-war Bosnia \& Herzegovina." CEPDP 777.

Koolwal, Gayatri B. (2007). "Son preference and child labor in Nepal: The household impact of sending girls to work." World Development 35(5): 881-903. 
Kreutz, Joakim. (2005). "The armed conflict termination dataset codebook." Retrieved 23/04/2010, from http://www.pcr.uu.se/publications/UCDP_pub/UCDP\%20Conflict\%20Termination\%20Dataset\%20Cod ebook.pdf.

Lichbach, Mark I. (1989). "An evaluation of 'does economic inequality breed political conflict?' studies." World Politics 41(4): 435-445.

Lubkemann, Stephen C. (2008). Culture in chaos: An anthropology of the social condition in war. Chicago, University of Chicago Press.

Miguel, Edward and Gérard Roland (2006). "The long run impact of bombing Vietnam." NBER Working Paper W11954.

Münkler, Herfried (2005). The new wars (Die neuen Kriege). Cambridge, Polity Press.

Mvukiyehe, Eric and Cyrus Samii. (2008/9). "Laying a foundation for peace? A quantitative impact evaluation of united nations operations in Cote d'Ivoire (with technical appendix)." Retrieved 07/04/2010, from UN Office of Internal Oversight Services (December 2008). Basis of UN-OIOS report to the UN General Assembly A/63/713 (February 2009).

Nathanson, Vivienne (2000). "Preventing and limiting suffering should conflict break out: The role of the medical profession." International Review of the Red Cross 839: 601-615.

Nillesen, Eleonora and Philip Verwimp (2010). "A Phoenix in Flames? Portfolio Choice and Violence in Civil War in Rural Burundi." HiCN Working Paper 75.

Petersen, Roger (2001). Resistance and rebellion: Lessons from eastern Europe. Cambridge, Cambridge University Press.

Platteau, Jean-Philippe (1991). Traditional systems of social security and hunger insurance: Past achievements and modern challenges. Social security in developing countries. E. Ahmad, J. Drèze, J. Hills and A. K. Sen. Oxford, Clarendon Press: 112-170.

Restrepo, Jorge A., Michael Spagat and Juan Vargas (2004). "The dynamics of the Colombian civil conflict: A new dataset. Homo oeconomicus." Institute of SocioEconomics 21: 396-429.

Richards, Paul (1996). Fighting for the rainforest: War, youth and resources in sierra Leone. London, James Currey Publishers.

Roberts, Les, Riyadh Lafta, Richard Garfield, Jamal Khudhairi and Gilbert M. Burnham (2004). "Mortality before and after the 2003 invasion of Iraq: Cluster sample survey." The Lancet 364: 1857-1864.

Rodriguez, Catherine and Fabio Sanchez (2009). "Armed conflict exposure, human capital investments and child labor: Evidence from Colombia." HiCN Working Papers 68.

Sambanis, Nicholas (2001). "Do ethnic and nonethnic civil wars have the same causes? A theoretical and empirical inquiry (part 1). ." Journal of Conflict Resolution 45(3): 259-282.

Samii, Cyrus, Michael Gilligan and Kristine Eck (2009). "Nepal peacebuilding survey: Study design, December 10, 2009." 
Schindler, Kati (2008). "Time allocation, gender and norms: Evidence from post-genocide Rwanda."

Shemyakina, Olga (2006). "The effect of armed conflict on accumulation of schooling: Results from Tajikistan." HiCN Working Papers 12.

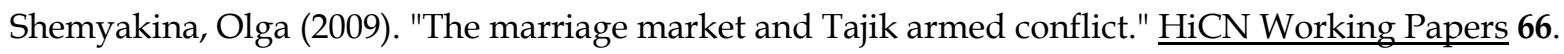

Singer, J. David and Melvin Small (1994). Correlates of war project: International and civil war data, 18151992. Ann Arbor, Michigan, Inter-university Consortium for Political and Social Research.

Singh, Inderjit, Lyn Squire and John Strauss (1986). Agricultural household models: Extensions, applications and policy. Baltimore, MD, Johns Hopkins University Press.

Spagat, Michael, Andrew Mack, Tara Cooper and Joachim Kreutz (2009). "Estimating war deaths: An arena of contestation." Journal of Conflict Resolution 53: 934-950.

Swee, Eik Leong (2009). "On war and schooling attainment: The case of Bosnia and Herzegovina." HiCN Working Paper 57.

Totten, Samuel and Eric Markusen (2006). Genocide in Darfur: Investigating the atrocities in the Sudan, Taylor \& Francis Group, LLC.

UNHCR, United Nations High Commissioner for Refugees. (2010). "Asylum levels and trends in industrialized countries 2009: Statistical overview of asylum applications lodged in Europe and selected non-European countries. Division of programme and support management." Retrieved 06/06/2010.

Uppsala Conflict Data Program (UCDP)/ International Peace Research Institute, Oslo (PRIO). (2007). "UCDP/PRIO armed conflict dataset codebook." Retrieved 07/04/2010, from http://www.pcr.uu.se/publications/UCDP_pub/UCDP_PRIO_Codebook_v4-2007.pdf.

Van Dijk, Jan, John van Kesteren and Paul Smit (2004/5). Criminal victimization in international perspective, key findings from the 2004-2005 ICVS and EU ICS. The Hague, Boom Legal Publishers.

Vasquez, John A. and Brandon Valeriano (2010). "Classification of interstate wars." The Journal of Politics 72(02): 292-309.

Verpoorten, Marijke (2009). "Household survey coping in war- and peacetime: Cattle sales in Rwanda, 1991-2001." Journal of Development Economics 88(1): 67-86.

Verpoorten, Marijke (2010). "Detecting hidden violence: The spatial distribution of excess mortality in Rwanda." LICOS - Centre for Institutions and Economic Performance, K.U. Leuven, LICOS Discussion Papers 25410.

Verwimp, Philip (2003). "Testing the double genocide thesis for central and southern Rwanda." Journal of Conflict Resolution 47(4): 423-442.

Verwimp, Philip (2005). "An economic profile of peasant perpetrators of genocide: Micro-level evidence from Rwanda." Journal of Development Economics 77: 297-323.

Verwimp, Philip, Patricia Justino and Tilman Brück (2009). "The analysis of conflict: A micro-level perspective." Journal of Peace Research 46(3): 307 - 314. 
Verwimp, Philip and Tom Bundervoet (2009). "Civil War and the Welfare of Extended Households: Evidence from Longitudinal Data from Burundi", HiCN Working Paper 70.

Voors, Maarten, Eleonora Nillesen, Philip Verwimp, Erwin Bulte, Robert Lensink and Daan van Soest (2009). "Does conflict affect preferences ? Evidence from field experiments in Burundi." HiCN Working Paper 71.

WDR, World Development Report (2011). "Conflict and development."

Weinstein, Jeremy M. (2007). Inside rebellion: The politics of insurgent violence. New York, Cambridge University Press.

WHO, World Health Organization. (2004). "Guidelines for conducting community survey surveys on injuries and violence." Retrieved 07/04/2010, from http://whqlibdoc.who.int/publications/2004/9241546484.pdf.

Wood, Elisabeth Jean (2003). Insurgent collective action and civil war in El Salvador. New York, Cambridge University Press. 